\title{
1. A linear inverse method to reconstruct paleo-topography
}

\author{
2 \\ Matthew Fox \\ Department of Earth Sciences, University College London, Gower Street, London, WC1E 6BT, \\ United Kingdom \\ Author email-address: m.fox@ucl.ac.uk (M.Fox)
}

\section{Abstract}

Landscape evolution provides insight into the tectonic and erosional processes that have shaped the topography observed today. However, in many cases, an estimate of an earlier topography is required to make first-order interpretations about volumes of sediment eroded or depths of fluvial incision, or to serve as an initial condition in landscape evolution models. This paper presents a means to reconstruct paleo-topography in two dimensions in areas that have experienced an increase in incision using available topographic remnants, or areas of low erosion rate. The approach is based on an analytical solution to the steady state stream power model in which a single elevation within the drainage network is a function of the integrated channel steepness and the normalized landscape response time, or $\chi$, values. The branching structure of a drainage network provides redundant information that can be exploited to infer spatial variations in channel steepness and a baselevel parameter. A single elevation pixel can be written as a sum of channel steepness multiplied by $\Delta \chi$ values, and a set of elevation pixels can be combined as a system of equations. In order to improve efficiency, channel steepness is parameterized using pixels of constant values. By incorporating smoothness constraints on the channel steepness pixels using a Laplacian opera- 
tor, a stable solution to the inverse problem can be obtained to infer the channel steepness values in space, a baselevel parameter and, in turn, paleo-topography. This approach is explored with examples from the Inyo Mountain Range, USA, Grand Canyon, USA and the Karrat Region in Western Greenland.

7 Keywords: landscape evolution modeling; fluvial incision; Grand Canyon;

8 Greenland

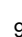

10

\section{Introduction}

The first order response of landscapes to changes in tectonics and climate has been studied since the work of Davis (1899) and formalized by Penck et al. (1972). In the context of fluvial systems, river channels respond to an increase in the rate of rock uplift by steepening. The transient response to this steepening results in a perched relict landscape above steepened reaches separated by knickpoints, which migrate upstream into the relict landscape. In some cases, this relict landscape contains information about the paleo-tectonics of the region and the total amount of incision surrounding the relict landscape provides an indication of the magnitude of rock uplift (e.g., Schoenbohm et al., 2004; Clark et al., 2005). Similarly, the response to changes in climate can be recorded in the topography with most most dramatic evidence for the role of climate change on topography being deep glacial U-shaped valleys with prominent hanging valleys. An estimate of a relict landscape, prior to the formation of deep valleys, can be estimated by reconstructing a preglacial topography (Sternai et al., 2012). This landscape can then be used to estimate how deeply glaciers have eroded, with respect to erosion on the low-relief surrounding areas (Steer et al., 2012), and to reconstruct sediment volumes that have been deposited down slope. Furthermore, it can be used to pro- 
vide more accurate boundary conditions to simulate the growth of early glaciers and interpret glacial moraines, which requires a topography for ice sheets to develop on. In both cases, reconstructing relict landscapes is required to interpret data constraining erosion rate and to serve as an initial condition in landscape evolution models (Demoulin et al., 2017; Briant et al., 2018). Furthermore, there is currently no algorithm that is routinely used to generate initial conditions for landscape evolution models and these must be specified by the user.

Reconstructing relict landscapes from digital elevation models (DEMs) of the present landscape has been achieved using several different methods. Each with different strengths and weaknesses.

In the case of testing landscape evolution models, it is often appropriate to simply scale modern topography by a relief factor. This results in a topography that has the same general form as modern topography but has a lower relief (e.g., Pelletier, 2010; Glotzbach et al., 2011). The absolute elevation of the topography can be modified so that the highest peaks in the low relief landscape and the current topography are at the same elevations. A potential limitation of this approach is that incised portions of the landscape are incorporated into the paleo-topography but with smaller magnitude, and the relief across any part of the preserved relict landscape is also reduced, even though the true relief is known in these locations. Furthermore, slope-area relationships are distorted in a way that may, or may not, follow the expected power-law relationship (Hack, 1973). A considerable benefit of this approach is that the resolution of the relict topography is the same as the modern topography, both in terms of absolute pixel size and in terms of drainage density.

An alternative simple approach requires finding an envelope that follows the 
highest points in a landscape, without requiring that the relict topography has the same form as the modern topography. In one dimension, along a river or glacial profile, this is equivalent to extrapolating a flat topography above the profile from the highest point of the profile assuming a flat relict landscape. In this case, the original landscape consists of the landscape above the knickpoint and a flat profile extrapolated above the modern profile. In two dimensions, a sliding window is often used. In this approach, a search radius is defined around a specific node on the DEM and the highest point within that radius is assigned to that node to generate a relict landscape (Gabet et al., 2004; Steer et al., 2012). This is then applied to each node in the DEM, forming a smooth surface. The search radius controls the degree to which the relict landscape follows the present landscape: a very small radius results in a relict topography that follows the present landscape; a very large radius results in a flat relict landscape; and, an intermediate radius provides a landscape free from deep and narrow valleys. In some cases, it may be possible to identify remnants of a relict topography, either through an automated selection procedure or by hand. These remnants can then be isolated and a surface interpolated between these remnants (Small and Anderson, 1998; Oskin and Burbank, 2005; Van der Beek and Bourbon, 2007; West et al., 2013; Stokes et al., 2018) using a range of different interpolation schemes with different benefits (Geach et al., 2014; Van Gorp et al., 2015). The result of this approach is a relict landscape that is constrained at these pre-selected locations. As with the case of scaling topography, a potential problem with these approaches is that the relict landscape may not exhibit expected features of the topography. As well as a lack of slope-area scaling, the drainage density will be very different and the drainage patterns may unrealistic with local depressions and large areas with par- 
allel rivers. This approach does provide a 2D surface that can be readily used in landscape evolution scenarios and models.

In order to generate landscapes that are more realistic, the expected relationship between channel slope and upstream drainage area can be used to generate paleo-topography. In 1D, along a long profile of a river or glacier, this requires fitting a curve that follows a slope-area relationship (Flint, 1974). This relationship can be defined so that the relict topography has the same peak elevation as the modern topography or is constrained based on incision estimates (e.g., Valla et al., 2011). When there is sufficient relict topography preserved in the landscape (which will depend on the scale and resolution of the DEM), topography above knickpoints can be used to construct a slope-area plot, from which a steepness index and concavity index can be extracted (Howard and Kerby, 1983; Tucker and Slingerland, 1994; Whipple and Tucker, 1999). In turn, these parameters can be used to reconstruct slopes, and thus, elevations downstream of knickpoints (e.g., Schoenbohm et al., 2004; Clark et al., 2005; Harkins et al., 2007; Berlin and Anderson, 2007; Kirby and Whipple, 2012; Schildgen et al., 2012; Darling and Whipple, 2015). This same approach can be used in 2D problems, however, reconstructed river tributaries may not agree with reconstructed main channels. These discrepancies can be explained by, and exploited to infer, different stages of incision (Matthes, 1972) or spatial variations in channel steepness (Sternai et al., 2012).

In Sternai et al. (2012), the baselevel was assumed to be constant and channel heads were used to define relief on the fluvial network. Channel head elevations were predicted by integrating channel slopes along the river network, where channel slope is defined by an expected relationship between slope and upstream 
drainage area (Flint, 1974). The local channel steepness values were free parameters and these were estimated by fitting the reconstructed channel heads to the observed channel heads. In order to find the best-fit channel steepness values, an iterative process was used in which channel steepness values were perturbed with respect to the current model and if the perturbation improved the fit, the current model was updated. Each perturbation to the current model was in the form of 2D Gaussian functions so that several predicted channel heads were perturbed each time. This enabled a stable solution to be found, despite the non-uniqueness of the inverse problem. However, as the perturbations were proposed in a random way, the chance of proposing a beneficial perturbation at a suitable location was relatively low and thus the solution is slow. This chance also decreases as the total number of nodes describing the network increases. Furthermore, there is no guarantee that a global minimum is found and the iterative process could become trapped in a local misfit minimum.

This paper presents a method to reconstruct paleo-topography from DEMs. The method is similar to other approaches that utilize the expected relationship between channel slope and upstream drainage area. However, here the analytical solution to the detachment-limited stream power model is used. This means that slopes from DEMs are not required and linear inverse methods can be exploited, providing robust results that are not strongly influenced by noise and greatly increasing the speed of the $2 \mathrm{D}$ problem. 


\section{Method}

\subsection{The stream power model and preservation of relict topography}

The detachment-limited stream power model relates erosion rate to: the change in elevation $z$ along the length of the channel, $x$, giving local slope $d z / d x$ raised to the power of $n$; discharge that is commonly simplified as the upstream drainage area, $A$, raised to the power of $m$; and the erosional efficiency, $K$, that accounts for bedrock lithology, bedload and climatic conditions. The evolution of the elevation within the fluvial network is expressed as:

$$
\frac{\partial z(t, x)}{\partial t}=u(t, x)-K A(x)^{m}\left(\frac{\partial z(t, x)}{\partial x}\right)^{n}
$$

where $t$ is time and $u(t, x)$ is the rate of tectonic rock uplift that can vary as a function of space and time. $m$ and $n$ are positive constants, and the appropriate values are debated (Howard and Kerby, 1983; Seidl and Dietrich, 1993; Tucker and Slingerland, 1994; Whipple and Tucker, 1999; Attal et al., 2008; Whittaker and Boulton, 2012). Here, we assume values of $m$ of $0.3-0.5$ which can be inferred from the data (Willett et al., 2014) and n of 1 discuss this choice below.

The solution for the linear version (i.e., $n=1$ ) of the stream power model at a position $x$ from the baselevel at the present day can be written as an integral of the rock uplift rate at different downstream spatial locations between now and the response time of position $x$ (Royden and Perron, 2013; Goren et al., 2014):

$$
z(0, x)=\int_{-\tau(x)}^{0} u\left(t^{\prime}, \tau^{1}\left(\tau(x)+t^{\prime}\right)\right) d t^{\prime}
$$

where $\tau(x)$ is the length of time that knickpoints take to travel from the baselevel, at $x=0$, to a point $x$ upstream (Rosenbloom and Anderson, 1994) given as a 
function of distance and upstream drainage area:

$$
\tau(x)=\int_{0}^{x} \frac{d x^{\prime}}{K A\left(x^{\prime}\right)^{m}},
$$

when $n=1$. $\tau^{1}\left(\tau(x)+t^{\prime}\right)$ provides a mapping between time and the spatial location of the relevant rock uplift rate required for the integration.

The response time is a function of the distribution of upstream drainage area within the catchment and the erosional efficiency, $K$, Eqn. 3. In practical terms, this is very challenging to estimate because $K$ must be determined using independent erosion rate data (Whipple and Tucker, 1999; Bishop et al., 2005; Berlin and Anderson, 2007; Roberts and White, 2010; Roberts et al., 2012; Fox et al., 2014; Goren et al., 2014) and often this data is unavailable. To negate the need to know $K$, Royden and Perron (2013) introduced the $\chi$ metric, which is a variable transformation for the length of a fluvial profile accounting for the distribution of upstream drainage area. This means that knickpoints that were formed at the baselevel, and will have travelled different distances from the baselevel, will be located at the same $\chi$ value. In turn, plots of $\chi$-elevation provide a means to visualize shared characteristics of rivers with different upstream drainage area distributions. The $K$ independent analytical solution relates the present elevation of a location in the drainage network at a distance of $x$ from the baselevel, to rock uplift rate normalized by the erosional efficiency:

$$
z(0, x)=\int_{-\chi(x)}^{0} u^{*}\left(t^{\prime}, \chi^{1}\left(\chi(x)+t^{\prime}\right) d t^{\prime}\right.
$$

where, 


$$
\chi=A_{0}^{m} K \tau,
$$

and $A_{0}$ is an scaling area so that $\chi$ has units of length (Perron and Royden, 2013), and $u^{*}$ is the normalized rock uplift rate. It is important to note that the normalized rock uplift rate is proportional to the familiar channel steepness index in the stream power model provided a consistent value of $m$ is used (Royden and Perron, 2013; Perron and Royden, 2013; Fox et al., 2014; Goren et al., 2014; Mudd et al., 2014).

Within this framework, relict topography exists at locations above a specific $\chi$ value and this value will correspond to a specific time in the past determined by the value of $K$. If this relict landscape can be identified, we can write an expression for this topography in terms of local normalized rock uplift rate and catchment baselevel,

$$
z(0, x)_{r}=\text { B.L. }+\int_{-\chi(x)}^{0} u^{*}\left(t^{\prime}, x\right) d t^{\prime},
$$

where $z(0, x)_{r}$ corresponds to a position $x$ from the baselevel at the present day within the relict landscape. For the purposes of reconstructing paleo-topography, we make the simplification that the paleo-topography was in steady state prior to a change in incision. We make this simplification because the relict topography that we analyze may not contain sufficient information on the rock uplift rate history due to the influence of glacial erosion, transient divide migration and unaccounted for complexities. Instead we seek a topography that is representative of the paleotopography in terms of paleo-relief and drainage geometry, which is probably adequate, and an improvement, for most applications.

With a steady state assumption and for a discrete representation of a drainage 
network using a series of nodes, for nodes along the main trunk of the river, the expression reduces to:

$$
z(i)_{r}=B . L .+\sum_{j=1}^{i}\left(\chi(j)-\chi(j-1) u^{*}(j),\right.
$$

so that the normalized rock uplift rate only varies as function of space.

\section{2. $1 D$ inverse solution}

The one-dimensional inverse problem is equivalent to fitting a river profile through the relict topography and propagating this profile above the incised landscape to determine the baselevel. To further simplify this problem and to account for the limited constraints on the relict topography, we make the assumption that the normalized rock uplift rate is constant in space and that the relict topography was in equilibrium with an earlier normalized rock uplift rate. Therefore we can write,

$$
z(x)_{r}=\text { B.L. }+\chi(x) u^{*}
$$

This relationship can easily be visualized and relict portions of a landscape should plot as a straight line on a $\chi-z$ plot with the slope equal to $u^{*}$ and the intercept providing the baselevel, assuming that uplift is spatially invariant. The paleo-topography can then be generated by using the best-fit parameters (the slope and the intercept, corresponding to $u^{*}$ and B.L.) for all portions of the landscape.

Formally, we can write Eqn. 8 for all $n$ relict nodes in the 1D profile as : 


$$
\left[\begin{array}{cc}
\chi(1) & 1 \\
\chi(2) & 1 \\
\cdots & \cdots \\
\chi(n) & 1
\end{array}\right]\left[\begin{array}{c}
u^{*} \\
\text { B.L. }
\end{array}\right]=\left[\begin{array}{c}
z(1)_{r} \\
z(2)_{r} \\
\cdots \\
z(n)_{r}
\end{array}\right]
$$

or in matrix form as

$$
\mathrm{Gr}=\mathbf{z},
$$

where $\mathbf{G}$ is a $n \times 2$ matrix containing values of $\chi$ and ones (as described in Eqn. 9), $\mathbf{r}$ is a vector containing the parameters required to calculate the relict topography (normalized rock uplift rate and the baselevel), and $\mathbf{z}$ is a vector of elevations. Solving this system of equations to gain an estimate of the model parameters, $\hat{\mathbf{r}}$, requires solving:

$$
\hat{\mathbf{r}}=\left(\mathbf{G}^{T} \mathbf{G}\right)^{-1} \mathbf{G}^{T} \mathbf{z}
$$

\section{3. $2 D$ inverse solution}

The two dimensional inverse problem is also equivalent to fitting a river profile through parts of the relict topography and propagating this profile above the incised landscape. However, there may be discrepancies between the reconstructed profiles at tributaries. These discrepancies provide constraints on how the normalized rock uplift rate varies in space. For example, if the trunk river flows through two different zones of rock uplift rate, a change in steepness would be expected along the length of the trunk channel. However, if relict landscape is only preserved in the upper reaches of the trunk river, no indication of the two 
zones would be preserved in the trunk stream and thus the estimate of the baselevel would be over- or under-estimated. If there are tributaries sampling both uplift rate zones that preserve relict parts of the landscape in their upper reaches, these tributaries provide an indication of the regional normalized rock uplift rate. Ultimately, incorporating tributaries to determine regional normalized rock uplift rate will improve the estimate of the baselevel and the accuracy of the recovered topography.

Importantly, without the requirement that the normalized rock uplift rate is uniform in space, there are many more values of the normalized rock uplift rate. For example, in Eqn. 7, an elevation node in the relict landscape is a function of the normalized rock uplift rate at every downstream node and there will always be fewer relict nodes than there are river nodes in the total drainage network. In this respect, the $2 \mathrm{D}$ problem is under-constrained and additional constraints, in the form of smoothness constraints, can be used to estimate the model parameters.

We utilize the same approach as the $1 \mathrm{D}$ inversion to estimate the parameters controlling the relict topography. For a single node in a catchment along the main trunk of the river, we have:

$$
\left[\begin{array}{llllll}
\chi(1) & \chi(2) & \chi(3) & \ldots & \chi(i) & 1
\end{array}\right]\left[\begin{array}{c}
u^{*}(1) \\
u^{*}(2) \\
u^{*}(3) \\
\ldots u^{*}(i) \\
B . L .
\end{array}\right]=\left[z(i)_{r}\right]
$$

Tributary nodes will also have similar expressions, however the exact summation depends on how the drainage network nodes are ordered and the summation will 
be from the baselevel upstream through the drainage network. For example two relict landscape nodes $z(5)_{r}$ and $z(6)_{r}$ are one node upstream of a confluence at $z(4)$, which is not part of the relict landscape. The expressions for these nodes can be written as,

$$
\left[\begin{array}{ccccccc}
\chi(1) & \chi(2) & \chi(3) & \chi(4) & \chi(5) & 0 & 1 \\
\chi(1) & \chi(2) & \chi(3) & \chi(4) & 0 & \chi(6) & 1
\end{array}\right]\left[\begin{array}{l}
u^{*}(1) \\
u^{*}(2) \\
u^{*}(3) \\
u^{*}(4) \\
u^{*}(5) \\
u^{*}(6) \\
B . L .
\end{array}\right]=\left[\begin{array}{l}
z(5)_{r} \\
z(6)_{r}
\end{array}\right] .
$$

Here the elevation of both nodes is a function of the normalized uplift rate downstream of the confluence, and the baselevel. The elevations of $z(5)_{r}$ and $z(6)_{r}$ are also functions of $u^{*}(5)$ and $u^{*}(6)$, respectively. This simple example highlights the degree of non-uniqueness of this problem as there are many more unknowns than constraints. To simplify the problem we reduce the number of nodes describing the river network in between confluences, by removing nodes where the drainage area does not increase by a user-defined factor. However, even if all nodes that were not confluences were removed, the problem would still be non-unique because the baselevel is also a free parameter. Therefore, we introduce additional smoothness constraints to increase the stability of the solution and to average out noise creating smooth normalized steepness maps.

Smoothness constraints are implemented by further discretizing the problem 
into pixels of size $\Delta x \times \Delta y$. (Here we refer to pixels to define this grid and nodes to refer to the discretization of the river network). For this discretization, any nodes in the drainage network that fall within a given pixel are forced to have the same normalized uplift rate. For example, in equation 12, if the first two nodes of the river network fall in the first pixel they will have the same uplift rate, $u_{p}^{*}(1)$. Therefore, we can write a summation expression in terms of this discrete grid:

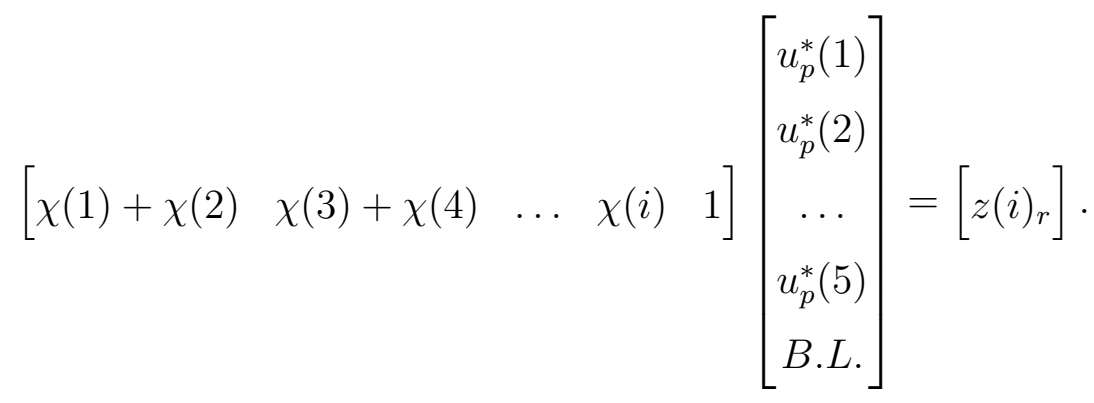

Expressions for each node in the relict landscape can be written and combined in matrix form:

$$
\operatorname{Ar}_{\mathbf{p}}=\mathbf{z}
$$

where $\mathbf{A}$ is a matrix of size $n \times\left(n_{p}+1\right), n$ is the total number of relict nodes and $n_{p}$ is the number of pixels used for the discretization, the additional column of $1 \mathrm{~s}$ is to account for the baselevel parameter. For a given elevation node, the corresponding row of $\mathbf{A}$ will contain blocks of $\chi$ values that sum to the corresponding $\chi$ of the given elevation node. $\mathbf{r}_{\mathbf{p}}$ is a vector of length $n \times\left(n_{p}+1\right)$ containing the values used to describe relict landscape, i.e., the normalized uplift rates in the discretized form and the baselevel parameter. $\mathbf{z}$ is a vector of length $n$ and contains the elevations of relict nodes. 
In order to solve the under-constrained inverse problem, smoothness constraints are directly incorporated into Eqn. 15 and solving this expression provides smooth maps of $u^{*}$ that is consistent with the data. A discrete Laplacian is used to quantify roughness (Constable et al., 1987). This form of a Tikhonov regularization has been used extensively within the Earth Sciences from 3D seismic tomography (e.g., Sambridge, 1990), to heat flow problems (e.g., Gallagher and Sambridge, 1992), and from slip distributions on fault planes during earthquakes (e.g., Segall and Harris, 1987), inferring uplift rates from river profiles (e.g., Goren et al., 2014) to generating elemental maps of individual crystals (Fox et al., 2017b).

A smoothness, or roughness, constraint is incorporated into the analysis by adding additional terms to Eqn. 15 that penalize rough pixel values. A single expression describing roughness around an individual pixel can be written as:

$\lambda \nabla^{2} u^{*}(l, m)=4 * u^{*}(l, m)-u^{*}(l+1, m)-u^{*}(l-1, m)-u^{*}(l, m+1)-u^{*}(l, m-1)$,

where $\lambda$ provides a relative weight that will be discussed below and the indices $l$ and $m$ are the co-ordinates of a given pixel. For example, when the surrounding pixels, $u^{*}(l+1, m), u^{*}(l-1, m), u^{*}(l, m+1)$ and $u^{*}(l, m-1)$, are similar to the central pixel $u^{*}(l, m), \lambda \nabla^{2} u^{*}(l, m)$ is small, indicating a low degree of roughness. In order to incorporate these expressions, we combine Eqn. 15 with the smoothness constraints given by Eqn. 16 resulting in a modified system of equations: 


$$
\left(\begin{array}{c}
\mathbf{A} \\
\cdots \\
\lambda \nabla^{2}
\end{array}\right) \mathbf{r}_{\mathbf{p}}=\left(\begin{array}{c}
\mathbf{z} \\
\cdots \\
\mathbf{0}
\end{array}\right)
$$

The least squares approach minimizes both the fit to the data and the roughness of the model and the total misfit can be defined as, $\phi$ :

$$
\phi=\left\|\mathbf{A r}_{\mathbf{p}}-\mathbf{z}\right\|^{2}+\lambda^{2}\left\|\nabla^{\mathbf{2}} \mathbf{r}_{\mathbf{p}}-\mathbf{0}\right\|^{2}
$$

When $\lambda$ is small, the righthand side expression, $\lambda^{2}\left\|\nabla^{2} \mathbf{r}_{\mathbf{p}}-\mathbf{0}\right\|^{2}$ is small and importance of this term decreases and the spatial roughness in $u^{*}$ does not control the value of $\phi$. Instead, $\phi$ will be minimized when the fit to the data $\left\|\mathbf{A r}_{\mathbf{p}}-\mathbf{z}\right\|^{2}$, is small. It is important to note, however, that this solution will attempt to fit geomorphic noise and the results could potentially be unrealistic. When $\lambda$ is large a smooth $u^{*}$ solution will be found in order to minimize $\lambda^{2}\left\|\nabla^{\mathbf{2}} \mathbf{r}_{\mathbf{p}}-\mathbf{0}\right\|^{2}$, which may not fit the data well. This solution may be useful to reduce the influence of geomorphic noise. Therefore, this trade-off between fit to the data and smooth results, must be explored when choosing a value for $\lambda$. As there is no way to assess whether or not a given paleo-topography is correct or not, an optimal value of $\lambda$ should be chosen based on obtaining reasonable results.

The basic steps in this process are shown in Fig. 1. In this cartoon, the initial topography is shown as the pre-incision topography. It is important to note that this initial topography is not an initial condition in the way that landscape evolution models require an initial condition and boundary conditions to solve differential equations. Instead, this pre-incision topography represents the unknown topography that we wish to recover. The forward model is highlighted on the 
left and this represents a simplified landscape evolution process from the initial topography to the modern topography. The inverse model and the steps required to solve this inverse model are described on the right. The first step is to extract the drainage network using a steepest descent algorithm. Once this network has been determined, $\chi$ values can be calculated at nodes along the network. The relict part of the landscape can be determined by inspecting the topography or through parametric criteria. Only the $\chi$ values and the elevations of the relict river nodes are used as data but additional nodes at confluences are required to solve the inverse problem, and so the network is filtered. The resulting network and discretized domain are used to build the A matrix, which describes the elevation of specific nodes as a function of the downstream distribution of $\chi$ values and an unknown vector of normalized rock uplift rate values and a baselevel parameter. This system of equations can be solved to determine this unknown vector using least squares inversion with spatial smoothness constraints.

\subsection{Analysis of Assumptions}

In order to infer paleo-topography, assumptions about the erosional properties operating on the paleo-topography have been made. Ultimately, the goal is to produce a paleo-topography that has characteristics of fluvial topography to be used to infer erosion rates for use with thermochronometric data or cosmogenic nuclide concentration data, as an initial condition for landscape evolution models and to produce topography that is suitable for use in ice sheet reconstructions. For these uses, the reconstructed topography should be an improvement over interpolation schemes or sliding window based methods, despite the assumptions listed below.

The interpolation scheme is based on the steady state stream power model and the expected relationship between channel slope and upstream drainage area. 
There are several complexities that are known to control the form of fluvial channels, such as variable channel width as a function of rock uplift rate (Lavé and Avouac, 2001; Finnegan et al., 2005; Turowski et al., 2006; Amos and Burbank, 2007; Attal et al., 2008; Yanites et al., 2010; Kirby and Ouimet, 2011), the sediment flux dependence on channel slope and incision (Sklar and Dietrich, 1998; Whipple and Tucker, 2002; Wobus et al., 2006; Lamb et al., 2008; Lague, 2010), and the resulting non-linear relationships between river slope and erosion rate (Howard and Kerby, 1983; Tucker and Slingerland, 1997; Lamb et al., 2007; Attal et al., 2008; Scheingross et al., 2017), and these are not accounted for. These complexities are likely to be important for transient landscapes and for inferring uplift rates from topography but will not influence the ability to reconstruct paleotopography to the accuracy required for many applications.

The methodology is based on the assumption that the shape of the river network, and the distribution of upstream drainage area, has remained constant between the time at which the reconstructed paleo-topography represents and today. There are, however, processes that will lead to upstream drainage area exchanging between catchments. Large scale capture of rivers caused by tilting at a large-scale (Clark et al., 2004; Wang et al., 2012; Wickert et al., 2013) or horizontal shear caused by regional tectonics (Ramsey et al., 2007; Castelltort et al., 2012; Goren et al., 2015; Yang et al., 2015; Gray et al., 2017) will have a large effect on the results. In addition, river networks may be continually adjusting and changing, leading to drainage divide migration and reorganization of river networks (Willett et al., 2014). The transfer of drainage area from one catchment to another during drainage divide migration causes a change in stream power along the length of both channels: the catchment gaining area will have increased stream power 
and the catchment losing area will have decreased stream power. Over time, rivers will respond to this change in stream power by increasing or decreasing channel slope and the timeframe of adjustment will be dependent on $K$. Therefore, if divide migration occurred recently with respect to the time represented by the paleo-topography, the drainage network would be unadjusted and regions of anomalously high and low channel normalized rock uplift rate will be identified. If there is migration of a small drainage divide between small catchments within a larger catchment, the pair of anomalously high and low normalized rock uplift rate values may be averaged out by the requirement that maps are smooth. If these features are not averaged out, they can be identified by the pair of anomalously high and low normalized rock uplift rate values in neighboring catchments (Fox et al., 2014).

The erosional efficiency, $K$, is assumed to be uniform in space and time. The effect of erodibility is challenging to quantify because although there is evidence that it is a function of lithology (Sklar and Dietrich, 2001; Duvall et al., 2004) and precipitation rate (Tucker and Slingerland, 1997; Burbank et al., 2003; Moon et al., 2011; Ferrier et al., 2013), there is also conflicting evidence suggesting that lithology (Riebe et al., 2001; Kirby et al., 2003; Ouimet et al., 2009; DiBiase et al., 2010; Kirby and Ouimet, 2011) and precipitation rate (Riebe et al., 2001; Burbank et al., 2003; Dadson et al., 2003; Von Blanckenburg, 2005; Wittmann et al., 2007) play a minor role in determining erodibility. If $K$ is not spatially uniform throughout the study area, changes in the normalized rock uplift rate map may be identified that are the result of spatial variations in $K$ not $u$. This may help to identify the importance of $K$ on controlling regional channel steepness. If, however, spatial variations in $K$ are expected to be causing apparent spatial 
variations in $u, \chi$ should be recalculated to account for these differences. This would then result in an iterative approach in which variations in $K$ are updated to ensure that any available geological data are predicted by the inferred rock uplift rate values.

\section{1D example: Inyo Mountains, CA, USA}

In this section, an example from the Inyo Mountains in the Basin and Range province is used to illustrate the method before presenting the $2 \mathrm{D}$ example. The Inyo Mountains are the most-western uplifted range within the Basin and Range province in California and have relief of approximately $3 \mathrm{~km}$, Fig. 2. The Eastern Inyo Fault is a normal fault that bounds the range to the east and has driven 1.5 $\mathrm{km}$ of exhumation since 2.8 Ma (Lee et al., 2009). Rivers draining the eastern flank of the Inyo Mountains, to the flat Saline Valley, have prominent knickpoints, that are unlikely to be the result of lithological variations (Streitz and Stinson, 1974; Ross, 1976). Therefore these rivers have been previously used to infer the rock uplift rate with respect to the sedimentary fill in the Saline Valley (Kirby and Whipple, 2012; Goren et al., 2014; Fox et al., 2015), using the same underlying assumptions adopted here. Results of these analyses show that from 4 to $3 \mathrm{Ma}$, rates are almost uniform at $\sim 0.4 \mathrm{~mm} / \mathrm{yr}$, then from $3 \mathrm{Ma}$ to $\sim 1$ Ma rock uplift rates increase gradually to $0.55 \mathrm{~mm} / \mathrm{y}$. This is followed by a faster increase to a value of $\sim 0.68 \mathrm{~mm} / \mathrm{yr}$ at about $1 \mathrm{Ma}$. This increase in uplift rate with respect to the Saline Valley results in knickpoints in the rivers draining to the Saline Valley in the Inyo Mountains.

The elevation and $\chi$ datasets required for the analysis were derived from the 30 m National Elevation Dataset (NED) DEM (Gesch, 2007). ArcGIS was used to 
calculate flow directions and upstream drainage areas for each pixel in the DEM. In order to define the drainage network and exclude hillslopes from the analysis, only pixels in the DEM with an upstream drainage area greater than $1-\mathrm{km}^{2}$ were analyzed.

McElvoy Canyon displays the clearest knickpoint, separating a relatively low channel slope profile at high elevations from a steeper segment at lower elevations (Fig. 3A). This trend can be clearly seen when elevation is plotted as a function of $\chi$ in Fig. 3B, calculated with $m=0.3$ and $A_{0}=10 \mathrm{~km}^{2}$, after Goren et al. (2014).

Based on the channel profile and $\chi-z$ relationship, an elevation of $750 \mathrm{~m}$ was chosen as the lowest point of the relict landscape. It is important to note that if this threshold elevation is underestimated (i.e., too low), parts of the incised landscape will be used to infer the channel steepness of the relict landscape and the paleo-basevel will be underestimated. This would result in an under-estimation in the amount of incision. If however, this threshold elevation, separating the relict landscape from the incised landscape, is overestimated (i.e., too high), fewer data points will be used in the linear regression resulting in a less well constrained model. Formal methods to pick the location of knickpoints (Mudd et al., 2014; Fox et al., 2015; Neely et al., 2017) could also be exploited, but because of the inherent uncertainties in the analysis, a trial and error approach to pick this threshold elevation should be sufficient.

Solving Eqn. 11 for only the fluvial nodes above the threshold elevation results in a slope of 0.1703 and a predicted baselevel of $335.71 \mathrm{~m}$. This results in a straight profile in the $\chi$-elevation plot (Fig. 3B). Using these parameters we can also predict the channel profile, A. 


\section{2D study: Grand Canyon, Az, USA}

Incision of Grand Canyon has been a long-standing geomorphic and geodynamic challenge of the last 150 years (e.g., Powell, 1875). The onset of incision has been determined through dating the arrival of detritus from Grand Canyon (Dorsey et al., 2007; Ingersoll et al., 2013; Lucchitta et al., 2013), dating basalt flows that drape topography or were emplaced prior to incision (Lucchitta et al., 2001), dating sediments that were transported across Grand Canyon prior to incision (Young, 1989), and by using landscape evolution models to simulate canyon incision and reproduce these observations (Pelletier, 2010). Thermochronometry has been used to study the direct and in situ incision of Grand Canyon (Flowers and Farley, 2012; Fox and Shuster, 2014; Karlstrom et al., 2014; Fox et al., 2017a; Winn et al., 2017). Recent thermochronometric studies provide support for a 'young' canyon model in which westernmost Grand Canyon is approximately 5-6 Ma old. These studies use cooling history as a proxy for exhumation, however thermal models that account for the advection of heat during exhumation, the advection of heat by fluids or the influence of topography on the thermal field, have not been used to convert cooling to exhumation. Both heat flow models for thermochronometric analysis and landscape evolution models require a pre-incision DEM.

In order to infer paleo-topography, a river network that can be used to calculate values of $\chi$ is required. The global hydrological database (Lehner et al., 2008), which has a resolution of $\sim 90 \mathrm{~m}$ and provides flow directions for each pixel in the DEM, was used. However, the Colorado River is a very large catchment and that makes calculating upstream drainage area challenging. Thus, a coarse grid, with a resolution of $\sim 450 \mathrm{~m}$ (Lehner et al., 2008), was used to calculate the upstream 
drainage area of the main channel of the Colorado River at the upstream limit of our analysis and all major rivers that drain into the study region. Using the fine grid, $\chi$ values for all nodes of a DEM with an upstream drainage area $>1 \mathrm{~km}^{2}$, using $A_{0}=1 \mathrm{~m}^{2}$ and a value of $m=0.5$ (Pelletier, 2010), were calculated as shown in Fig. 4.

Once the $\chi$ values were calculated using a fine grid, this was filtered to decrease the number of nodes and greatly decrease the computation time (Fig. 5). River nodes above $1400 \mathrm{~m}$ are assumed to be part of the relict topography and these nodes are used in the inversion. River nodes lower were only included in the data set if the upstream drainage area of the node is 5\% larger than the node downstream. This preferentially keeps confluences in the dataset. Eqn. 17 was solved for a range of $\lambda$ values to produce a baselevel values and maps of normalized rock uplift rate. Once these parameter values are calculated, they can be used to reconstruct topography on the unfiltered DEM.

At small values of $\lambda$, the approach attempts to fit each remnant river node perfectly, and data misfit is low as shown in Eqn. 18. The channel steepness values, however, vary over short wavelengths and this is unexpected across the Colorado Plateau (Fig. 6). As $\lambda$ is increased, a smoother model is predicted but data misfit would increase. A trial and error approach should be used to pick the value of $\lambda$ and the pixel size, based on obtaining models that are consistent with prior knowledge or field observations. For example, if there is a rapid change in channel steepness that is predicted by the model, but there is no evidence for changes in rock uplift rate or lithology at this location, then the model is likely fitting noise and a larger value of $\lambda$ should be used. In contrast, if there is evidence for large variations in rock uplift rate in the form of structural geological observations or 
thermochronometric data, and no variation in channel steepness is predicted by the model, $\lambda$ may be too large.

Estimated incision can be calculated by subtracting the reconstructed topography from the modern topography. It is important to note that this is not equal to the erosion because the relict relief may have been eroding during the time interval between now and the time represented by the reconstructed topography. In this respect, incision is defined as changes in the topographic surface while erosion is the change in the rocks exposed at the surface. For example, a steady state landscape may have very rapid rates of erosion but there may be no incision as the relief remains constant in time. Results show that across the relict portions of the landscape the incision is close to zero and the absolute value is sensitive to our choice of $\lambda$. In contrast, across Grand Canyon there has been significant incision, as expected (Fig. 7A). This can be clearly visualized by extracting the long profiles of the same river from the modern DEM and the reconstructed topography (Fig. 7B). The large steps in the modern profile are due to confluences and artifacts in the DEM, however this part of the topography is not used in the inversion.

\section{2D study: Karrat region, central West Greenland,}

The landscape of the Karrat region, central West Greenland, is heavily glaciated and includes elevated relatively low-relief topography that is approximately 2 $\mathrm{km}$ above sea level. This topography is believed to have formed through either widespread differential erosion and isostatic uplift (Medvedev et al., 2013; Jess et al., 2018) or late Cenozoic episodic uplift (Japsen et al., 2006; Bonow et al., 2014). For the illustrative example presented here, the mechanism of formation of 
the elevated topography is not required. Instead we seek a pre-incision topography that may have existed at some point in the past: a time before glacial erosion or before fluvial incision driven by an earlier phase of rock uplift. Recent analysis of cosmogenic nuclide concentrations across a range of elevations support the hypothesis of selective linear erosion (Sugden, 1974) in which glacial erosion rates can vary by orders of magnitude as a function of elevation (Strunk et al., 2017). Strunk et al. (2017) showed that the low-relief plateaus would effectively be preserved by low erosion rates ( $2 \mathrm{~m} / \mathrm{Myr}$ ) over glacial cycles due to cold-based ice which is frozen to the bedrock with low erosive potential, while the troughs were incised by thick, sliding ice resulting in higher erosion rates $(50 \mathrm{~m} / \mathrm{Myr})$. Therefore, it can be assumed that these high-elevation features of the topography can be used to reconstruct a pre-incision topography.

We use the Greenland bed map DEM produced by Morlighem et al. (2017) to calculate flow directions, $\chi$ values and extract high elevation surfaces to build the paleo-topography. Before calculating the drainage network, it is important to remove the load of the Greenland icesheet and calculate the isostatically adjusted topography using an effective elastic thickness of $20 \mathrm{~km}$ (Medvedev et al., 2013). The elastic response to this unloading has been previously explored by Medvedev et al. (2013) and results in 100s of meters of topographic change in the Karrat region. We use the ice thickness estimates from Morlighem et al. (2017), and a $20 \mathrm{~km}$ effective elastic thickness to calculate this elastic response in the frequency domain using GMT (Wessel et al., 2013). The resulting topography shows large overdeepenings (Fig. 8A) and the relatively low-relief areas can be seen in the corresponding slope map (Fig. 8B). The drainage network was extracted using GRASS and the TerraFlow package (Arge et al., 2003; Neteler et al., 2012). 
Once the drainage network was extracted and a depressionless DEM produced, noise was added to this depressionless DEM $( \pm 0.01 \mathrm{~m})$ and flow directions were re-calculated in an effort to reduce the artifacts caused by flat sections of topography. The extracted drainage network upstream of the Karrat region was filtered to reduce the dataset by $80 \%$ and is shown as a function of elevation and $\chi$ values, which were calculated with $m=0.45$ and $A_{0}=1 \mathrm{~m}^{2}$ for all pixels with an upstream drainage area greater than $1 \mathrm{~km}^{2}$ (Fig. 9A). The relict part of the topography was specified for elevations above $850 \mathrm{~m}$ for topographic slopes less than $0.6 \mathrm{~m} / \mathrm{m}$, (Fig. 9B), and these are used to infer the model parameters required to calculate the pre-incision landscape (Fig. 9D).

The inversion was carried out with a pixel size of $2.5 \mathrm{~km}$ and $\alpha=2.5$ as this provided a reasonable balance between data fit and model smoothness. The results highlight a region of large normalized rock uplift rate values in the centre of the model domain, as is expected given the associated region of high topography (Fig. 10A). A reconstructed river profile from the relict part of the landscape and through this area of high channel steepness towards the coast, shows gradual changes in channel slope that reflect these variations in inferred normalized rock uplift rate and the monotonic increase in upstream drainage area (Fig. 10B).

This example also highlights an additional complexity when working with DEMs that may not be hydrologically robust (Boulton and Stokes, 2018). In this case, the DEM has local sinks due to glacial overdeepenings. This results in a noisy along-channel topographic profile, as shown in Fig. 10B. Another feature caused by local sinks is seen in the central part of the inferred topography (Fig. 9A) where drainage directions have been inferred across a filled, and therefore flat, depression. This has resulted in several parallel 'rivers' that quickly lose 
upstream drainage area. When these artifacts are used to build the topography, they result in short steep rivers that are clearly not representative of a pre-incision topography. Fortunately, these are isolated features that could be removed if the DEM is required for further analyses.

\section{Discussion}

Landscape evolution modeling is crucial to interpret data constraining geomorphic processes and rates. For example, this data may constrain short-term processes such as dated strath terraces or cosmogenic nuclide concentration measurements or longer term processes in the form of thermochronometric data and sediment flux measurements. In these examples, an initial condition is required to run landscape evolution models forward in time to produce results that can be compared to observations. We have presented a means to generate an initial condition that maintains slope-area scaling, but allows for spatial variations in rock uplift rate. Some datasets may be insensitive to the initial condition, however, in places where a limited amount of data is available or where the degree of total incision is expected to be low, the initial condition becomes important. This is especially true for studying rates of landscape evolution on planetary surfaces, such as on Mars (e.g., Howard et al., 2005; Palucis et al., 2014).

The approach presented here assumes that a landscape prior to incision was close to steady state. It is possible to recreate multiple stages of landscape evolution if separate phases of landscape evolution can be identified independently. Alternatively, a complete uplift rate history could be extracted from river networks using inverse methods (Roberts et al., 2012; Fox et al., 2014; Goren et al., 2014; Rudge et al., 2015), and landscapes could be generated at specific time intervals. 
However, for the problem of interpolating between relict portions of topography, a simpler analysis is justified.

As others have previously noted (e.g., Schoenbohm et al., 2004; Harkins et al., 2007), the amount of erosion between the present and the time represented by the reconstructed landscape at any point in a landscape does not equal the difference between the reconstructed topography and the modern topography. This is because the channel segment above the knickpoint is eroding at a rate given by the steepness, upstream drainage area and the erodibility index. For example, a landscape may be in steady state with the regional rock uplift rate prior to a sudden increase in rock uplift rate. The landscape above knickpoints will continue to erode at the old regional rock uplift rate while below knickpoints, the erosion rate will be adjusted to the new rock uplift rate. The landscape below the knickpoints will be in steady state with the new rock uplift rate, but above the knickpoints surface uplift will occur. The incision rate into the relict landscape will thus be the difference between the new rock uplift rate and the old rock uplift rate.

Geomorphic noise in the dataset will result in short wavelength variations in normalized rock uplift rates and may occur due to several factors. Here, geomorphic noise is considered to be aspects of the topography that do not help constrain normalized rock uplift rates, and these aspects may be real or artifacts in the DEM (Boulton and Stokes, 2018). These artifacts may be due to an inability of the DEM to accurately record the deepest parts of canyons due to the canyon being narrower than the resolution of the DEM or from parts of the base of canyon being obscured by steep sides of the canyon. The artifacts may also be from flow routing algorithms that attempt to fill depressions, resulting in flat sections of topography and artificial steps and sills. 
Other physical aspects of topography that do not constrain normalized rock uplift rates include local variations in channel steepness due to regional variations in lithology, landslides and drainage divide migration. Local landslides can increase and decrease local channel steepness values by blocking rivers and subsequently being incised into. Landslides can also deliver material to rivers dramatically changing the bedload and therefore, the local slope of the river (Sklar and Dietrich, 2004; Ouimet et al., 2007). This is potentially problematic as landslide activity is expected to also correlate with changes in incision rate to some degree (e.g., Bennett et al., 2016).

Drainage divide migration and river capture is also treated as geomorphic noise. However, this is also potentially problematic as it may be possible that high elevation and low relief surfaces that are assumed to be remnants of relict landscape are actually formed by the processes of channel capture (Yang et al., 2015). For example, a steady state river channel will have channel slopes that increase with decreasing drainage area (Hack, 1973). This channel is expected to be eroding at a uniform and constant rate equal to the regional rock uplift rate. If however, the upper reaches of the channel are captured by a neighboring catchment, the upstream drainage area is dramatically reduced and the erosion rates also reduce. If the rock uplift rate remains constant, this low slope river segment will be advected upwards, ultimately becoming a low relief high elevation segment. Importantly, tests can be applied to discriminate between remnants of relict low relief landscapes and surfaces that have been formed through drainage divide migration and capture (Whipple et al., 2017).

By analyzing large datasets with multiple tributaries the influence of geomorphic noise can be reduced. This influence can also be reduced by finding a solution 
to the inverse problem that is very simple, either through large pixel sizes or large $\lambda$ values, so that more data are used to resolve a specific model parameter. It is important to note, however, that by attempting to reduce the influence of noise by incorporating more data the computational time and memory required to solve the inverse problem increases and the exact rate of increase depends on the topology of the drainage network. Furthermore, by finding a simple solution to the inverse problem, the ability to extract information from the topography is decreased, and this trade-off between sensitivity to noise and model resolution should be explored on a case-by-case basis.

The ability to infer the model parameters using the data and the forward model come from multiple sources. In the case of a 1D profile, the normalized rock uplift rate in the relict part of the landscape resolves the regional normalized rock uplift rate and the baselevel parameter. In this scenario, the relict topography is simply projected out across the incised part of the landscape, and multiple channel nodes within the relict landscape are required to determine the model parameters. In the case of a 2D drainage network, however, model resolution comes from this same process, but also from the fact that the normalized rock uplift rate at a specific point in the trunk channel influences the elevations of all points upstream of this point. Therefore, only a single node is needed within each area of relict landscape to infer a map of normalized rock uplift rates, however the model resolution will depend on how smoothly this map varies, how large the pixels are and the topology of the drainage network.

Both of the 2D examples presented here highlight an important advantage of using an appropriate forward model to generate a pre-incision topography over other interpolation methods. In the case of Grand Canyon, the Colorado River 
flows through the elevated topography of the Kaibab uplift. If a pre-incision topography was determined by fitting a surface through the low-relief topography above the rim of Grand Canyon, the drainage network that would be inferred would be very different: the Colorado River would be inferred to flow around the Kaibab uplift. If this topography was then used to test landscape evolution scenarios, it would be challenging to get the Colorado River to cut through this dome. Instead, the forward model forces the Colorado River to flow along the 'correct' path, which makes testing landscape evolution scenarios easier. This is also the case for the Karrat region in West Greenland, where the glaciers have incised through a region of high topography. A potential limitation of forcing the pre-incision topography to have the same drainage network as the modern topography is that there are likely to be scenarios where the drainage network has evolved, and this may be the focus of the research. In these scenarios, fitting a surface through remnant topography is required.

\section{Conclusion}

This paper has developed a new approach to reconstruct relict relief of fluvial networks. The approach is based on the analytical solution to the steady state stream power model in which the elevation of a specific channel node is the along channel integral of normalized rock uplift multiplied by $\chi$ from baselevel to the specific node. The modern channel network is used to calculate values of $\chi$ at the resolution of the DEM. However, only channel nodes that are chosen to be part of the relict landscape are used to reconstruct the full relict landscape, which is a function of the baselevel and normalized rock uplift rate that is free to vary in space. The preservation of the relict landscape determines how many data points 
are used in the analysis to infer normalized rock uplift rate. In turn, there will be no data points to constrain normalized rock uplift rates in area where the remnants of the relict landscape are not preserved. In this respect, the problem is underdetermined and smoothness constraints are required. In order to improve the time required to calculate values for normalized rock uplift rate as a function of space and a baselevel parameter, we discretize the problem using a grid and within a single grid pixel, the normalized rock uplift rate is constant. Each value of the normalized rock uplift rate grid is constrained by a combination of the channel pixels that are upstream of the grid pixel and by the requirement that normalized rock uplift rates vary smoothly in space. This smoothness constraint is imposed using a negative Laplacian operator.

A trade-off exists between the degree of smoothness and the fit to the channel nodes that are part of the relict landscape. Smooth solutions will define long wavelength variations in normalized rock uplift rate and be robust with respect to geomorphic noise, but may not fit the data well. Whereas, models that overfit the data, will be sensitive to geomorphic noise and long wavelength variations in normalized rock uplift rate may be obscured by short wavelength noise and artifacts. This is a common phenomenon when dealing with any interpolation routine and requires that users explore multiple solutions with a range of damping parameters before choosing a final solution.

\section{Acknowledgements}

I would like to thank L. Goren, M. Brandon, D. Shuster and K. Cuffey for stimulating discussions and B. Briant for providing information about initial conditions used in landscape evolution models. I also thank M. Stokes for a construc- 
699 tive formal review. Research was funded by NERC (NE/N015479/1). Figures

700 were prepared using the Generic Mapping Tools (Wessel et al., 2013). 


\section{References}

Amos, C. B., Burbank, D. W., 2007. Channel width response to differential uplift. Journal of Geophysical Research: Earth Surface 112 (F2), doi: 10.1029/2006JF000672.

Arge, L., Chase, J. S., Halpin, P., Toma, L., Vitter, J. S., Urban, D., Wickremesinghe, R., 2003. Efficient flow computation on massive grid terrain datasets. GeoInformatica 7 (4), 283-313, doi:10.1023/A:102552642.

Attal, M., Tucker, G. E., Whittaker, A. C., Cowie, P. A., Roberts, G. P., 2008. Modeling fluvial incision and transient landscape evolution: Influence of dynamic channel adjustment. Journal of Geophysical Research: Earth Surface 113 (F3), doi:10.1029/2007JF000893.

Bennett, G. L., Miller, S. R., Roering, J. J., Schmidt, D. A., 2016. Landslides, threshold slopes, and the survival of relict terrain in the wake of the Mendocino Triple Junction. Geology 44 (5), 363-366, doi:10.1130/G37530.1.

Berlin, M. M., Anderson, R. S., 2007. Modeling of knickpoint retreat on the Roan Plateau, western Colorado. Journal of Geophysical Research: Earth Surface 112 (F3), doi:10.1029/2006JF000553.

Bishop, P., Hoey, T. B., Jansen, J. D., Artza, I. L., 2005. Knickpoint recession rate and catchment area: The case of uplifted rivers in eastern Scotland. Earth Surface Processes and Landforms 30 (6), 767-778, doi:10.1002/esp.1191.

Bonow, J. M., Japsen, P., Nielsen, T. F., 2014. High-level landscapes along the margin of southern East Greenland-A record of tectonic uplift and incision 
after breakup in the NE Atlantic. Global and Planetary Change 116, 10-29, doi:10.1016/j.gloplacha.2014.01.010.

Boulton, S. J., Stokes, M., 2018. Which DEM is best for analyzing fluvial landscape development in mountainous terrains? Geomorphology 310, 168-187, doi:10.1016/j.geomorph.2018.03.002.

Briant, R. M., Cohen, K. M., Cordier, S., Demoulin, A. J., Macklin, M. G., Mather, A. E., Rixhon, G., Veldkamp, T., Wainwright, J., Whittaker, A., et al., 2018. Applying Pattern Oriented Sampling in current fieldwork practice to enable more effective model evaluation in fluvial landscape evolution research. Earth surface processes and landforms 43 (14), 2964-2980, doi: 10.1002/esp.4458.

Burbank, D., Blythe, A., Putkonen, J., Pratt-Sitaula, B., Gabet, E., Oskin, M., Barros, A., Ojha, T., 2003. Decoupling of erosion and precipitation in the Himalayas. Nature 426 (6967), 652-655, doi:10.1038/nature02187.

Castelltort, S., Goren, L., Willett, S. D., Champagnac, J.-D., Herman, F., Braun, J., 2012. River drainage patterns in the New Zealand Alps primarily controlled by plate tectonic strain. Nature Geoscience 5, 744-748, doi:10.1038/ngeo1582.

Clark, M. K., Schoenbohm, L. M., Royden, L. H., Whipple, K. X., Burchfiel, B. C., Zhang, X., Tang, W., Wang, E., Chen, L., 2004. Surface uplift, tectonics, and erosion of eastern Tibet from large-scale drainage patterns. Tectonics 23 (1), doi:10.1029/2002TC001402.

Clark, M. K., Maheo, G., Saleeby, J., Farley, K. A., 2005. The non-equilibrium landscape of the southern Sierra Nevada, California. GSA Today 15 (9), 4-10. 
Constable, S. C., Parker, R. L., Constable, C. G., 1987. Occam's inversion: A practical algorithm for generating smooth models from electromagnetic sounding data. Geophysics 52 (3), 289-300, doi:10.1190/1.1442303.

Dadson, S. J., Hovius, N., Chen, H., Dade, W. B., Hsieh, M. L., Willett, S. D., Hu, J. C., Horng, M. J., Chen, M. C., Stark, C. P., et al., 2003. Links between erosion, runoff variability and seismicity in the Taiwan orogen. Nature 426 (6967), 648-651, doi:10.1038/nature02150.

Darling, A., Whipple, K., 2015. Geomorphic constraints on the age of the western Grand Canyon. Geosphere 11 (4), 958-976, doi:10.1130/GES01131.1.

Davis, W. M., 1899. The geographical cycle. The Geographical Journal 14 (5), 481-504, doi:10.2307/1774538.

Demoulin, A., Mather, A., Whittaker, A., 2017. Fluvial archives, a valuable record of vertical crustal deformation. Quaternary Science Reviews 166, 10-37, doi: 10.1016/j.quascirev.2016.11.011.

DiBiase, R. A., Whipple, K. X., Heimsath, A. M., Ouimet, W. B., 2010. Landscape form and millennial erosion rates in the San Gabriel Mountains, CA. Earth and Planetary Science Letters 289 (1), 134-144, doi: 10.1016/j.epsl.2009.10.036.

Dorsey, R. J., Fluette, A., McDougall, K., Housen, B. A., Janecke, S. U., Axen, G. J., Shirvell, C. R., 2007. Chronology of Miocene-Pliocene deposits at Split Mountain Gorge, southern California: A record of regional tectonics and Colorado River evolution. Geology 35 (1), 57-60, doi:10.1130/G23139A.1. 
Duvall, A., Kirby, E., Burbank, D., 2004. Tectonic and lithologic controls on bedrock channel profiles and processes in coastal California. Journal of Geophysical Research: Earth Surface 109 (F3), doi:10.1029/2003JF000086.

Ferrier, K. L., Huppert, K. L., Perron, J. T., 2013. Climatic control of bedrock river incision. Nature 496 (7444), 206-209, doi:10.1038/nature11982.

Finnegan, N. J., Roe, G., Montgomery, D. R., Hallet, B., 2005. Controls on the channel width of rivers: Implications for modeling fluvial incision of bedrock. Geology 33 (3), 229-232, doi:10.1130/G21171.1.

Flint, J. J., 1974. Stream gradient as a function of order, magnitude, and discharge. Water Resources Research 10 (5), 969-973, doi:10.1029/WR010i005p00969.

Flowers, R., Farley, K., 2012. Apatite 4He/3He and (U-Th)/He evidence for an ancient Grand Canyon. Science 338 (6114), 1616-1619, doi: 10.1126/science.1229390.

Fox, M., Shuster, D. L., 2014. The influence of burial heating on the (U-Th)/He system in apatite: Grand Canyon case study. Earth and Planetary Science Letters 397, 174-183, doi:10.1016/j.epsl.2014.04.041.

Fox, M., Goren, L., May, D. A., Willett, S. D., 2014. Inversion of fluvial channels for paleorock uplift rates in Taiwan. Journal of Geophysical Research: Earth Surfacedoi:10.1002/2014JF003196.

Fox, M., Bodin, T., Shuster, D. L., 2015. Abrupt changes in the rate of Andean Plateau uplift from reversible jump Markov Chain Monte Carlo inversion of river profiles. Geomorphology 238, 1-14, doi: 10.1016/j.geomorph.2015.02.022. 
Fox, M., Tripathy-Lang, A., Shuster, D., Winn, C., Karlstrom, K., Kelley, S., 2017a. Westernmost Grand Canyon incision: Testing thermochronometric resolution. Earth and Planetary Science Letters 474, 248-256, doi: 10.1016/j.epsl.2017.06.049.

Fox, M., Tripathy-Lang, A., Shuster, D. L., 2017b. Improved spatial resolution of elemental maps through inversion of LA-ICP-MS data. Chemical Geologydoi: http://dx.doi.org/10.1016/j.chemgeo.2017.07.001.

Gabet, E., Pratt-Sitaula, B., Burbank, W., 2004. Climatic controls on hillslope angle and relief in the Himalayas. Geol 32, 629-632, doi:10.1130/G20641.1.

Gallagher, K., Sambridge, M., 1992. The resolution of past heat flow in sedimentary basins from non-linear inversion of geochemical data: the smoothest model approach, with synthetic examples. Geophysical Journal International 109 (1), 78-95, doi:10.1111/j.1365-246X.1992.tb00080.x.

Geach, M., Stokes, M., Telfer, M., Mather, A., Fyfe, R., Lewin, S., 2014. The application of geospatial interpolation methods in the reconstruction of Quaternary landform records. Geomorphology 216, 234-246, doi: 10.1016/j.geomorph.2014.03.036.

Gesch, D., Oimoen, M., Greenlee, S., Nelson, C., Steuck, M., Tyler, D., 2002. The national elevation dataset. PE \& RS- Photogrammetric Engineering \& Remote Sensing 68 (1), 5-11.

Gesch, D., 2007. The National Elevation Dataset. In: Maune, D. F. (Ed.), Digital elevation model technologies and applications: The DEM users manual. Asprs Pubns. 
Glotzbach, C., Van Der Beek, P. A., Spiegel, C., 2011. Episodic exhumation and relief growth in the Mont Blanc massif, Western Alps from numerical modelling of thermochronology data. Earth and Planetary Science Letters 304 (3), $417-$ 430, doi:10.1016/j.eps1.2011.02.020.

Goren, L., Fox, M., Willett, S. D., 2014. Tectonics from fluvial topography using formal linear inversion: Theory and applications to the Inyo Mountains, California. Journal of Geophysical Research: Earth Surface 119 (8), 1651-1681, doi:10.1002/2014JF003079.

Goren, L., Castelltort, S., Klinger, Y., 2015. Modes and rates of horizontal deformation from rotated river basins: Application to the Dead Sea fault system in Lebanon. Geology 43 (9), 843-846, doi:10.1130/G36841.1.

Gray, H. J., Shobe, C. M., Hobley, D. E., Tucker, G. E., Duvall, A. R., Harbert, S. A., Owen, L. A., 2017. Off-fault deformation rate along the southern San Andreas fault at Mecca Hills, southern California, inferred from landscape modeling of curved drainages. Geology 46 (1), 59-62, doi:10.1130/G39820.1.

Hack, J. T., 1973. Stream-profile analysis and stream-gradient index. Journal of Research of the US Geological Survey 1 (4), 421-429.

Harkins, N., Kirby, E., Heimsath, A., Robinson, R., Reiser, U., 2007. Transient fluvial incision in the headwaters of the Yellow River, northeastern Tibet, China. Journal of Geophysical Research: Earth Surface 112 (F3), doi: 10.1029/2006JF000570.

Howard, A. D., Kerby, G., 1983. Channel changes in badlands. Bulletin 
of the Geological Society of America 94 (6), 739-752, doi:10.1130/00167606(1983)94<739:CCIB>2.0.CO;2.

Howard, A. D., Moore, J. M., Irwin, R. P., 2005. An intense terminal epoch of widespread fluvial activity on early Mars: 1. Valley network incision and associated deposits. Journal of Geophysical Research: Planets 110 (E12), (?).

Ingersoll, R. V., Grove, M., Jacobson, C. E., Kimbrough, D. L., Hoyt, J. F., 2013. Detrital zircons indicate no drainage link between southern California rivers and the Colorado Plateau from mid-Cretaceous through Pliocene. Geology 41 (3), 311-314, doi:10.1130/G33807.1.

Japsen, P., Bonow, J. M., Green, P. F., Chalmers, J. A., Lidmar-Bergström, K., 2006. Elevated, passive continental margins: Long-term highs or Neogene uplifts? New evidence from West Greenland. Earth and Planetary Science Letters 248 (1-2), 330-339, doi:10.1016/j.epsl.2006.05.036.

Jess, S., Stephenson, R., Brown, R., 2018. Evolution of the central West Greenland margin and the Nuussuaq Basin: Localised basin uplift along a stable continental margin proposed from thermochronological data. Basin Research 30 (6), 1230-1246, doi10.1111/bre.12301.

Karlstrom, K. E., Lee, J. P., Kelley, S. A., Crow, R. S., Crossey, L. J., Young, R. A., Lazear, G., Beard, L. S., Ricketts, J. W., Fox, M., et al., 2014. Formation of the Grand Canyon 5 to 6 million years ago through integration of older palaeocanyons. Nature Geoscience 7 (3), 239-244, doi:10.1038/ngeo2065.

Kirby, E., Ouimet, W., 2011. Tectonic geomorphology along the eastern margin of Tibet: Insights into the pattern and processes of active deformation adjacent to 
the Sichuan Basin. Geological Society, London, Special Publications 353 (1), 165-188, doi:10.1144/SP353.9.

Kirby, E., Whipple, K. X., 2012. Expression of active tectonics in erosional landscapes. Journal of Structural Geology 44, 54-75, doi: 10.1016/j.jsg.2012.07.009.

Kirby, E., Whipple, K. X., Tang, W., Chen, Z., 2003. Distribution of active rock uplift along the eastern margin of the Tibetan Plateau: Inferences from bedrock channel longitudinal profiles. Journal of Geophysical Research: Solid Earth 108 (B4), doi:10.1029/2001JB000861.

Lague, D., 2010. Reduction of long-term bedrock incision efficiency by short-term alluvial cover intermittency. Journal of Geophysical Research: Earth Surface 115 (F2), doi:10.1029/2008JF001210.

Lamb, M. P., Howard, A. D., Dietrich, W. E., Perron, J. T., 2007. Formation of amphitheater-headed valleys by waterfall erosion after large-scale slumping on Hawaii. Geological Society of America Bulletin 119 (7-8), 805-822, doi: 10.1130/B25986.1.

Lamb, M. P., Dietrich, W. E., Sklar, L. S., 2008. A model for fluvial bedrock incision by impacting suspended and bed load sediment. Journal of Geophysical Research: Earth Surface 113 (F3), doi:10.1029/2007JF000915.

Lavé, J., Avouac, J. P., 2001. Fluvial incision and tectonic uplift across the Himalayas of central Nepal. Journal of Geophysical Research 106 (B11), 2656126, doi:10.1029/2001JB000359. 
Lee, J., Stockli, D. F., Owen, L. A., Finkel, R. C., Kislitsyn, R., 2009. Exhumation of the Inyo Mountains, California: Implications for the timing of extension along the western boundary of the Basin and Range Province and distribution of dextral fault slip rates across the eastern California shear zone. Tectonics 28 (1), doi:10.1029/2008TC002295.

Lehner, B., Verdin, K., Jarvis, A., 2008. New global hydrography derived from spaceborne elevation data. EOS, Transactions American Geophysical Union 89 (10), 93-94, doi:10.1029/2008EO100001.

Lucchitta, I., Jeanne, R. A., Young, R., Spamer, E., 2001. Geomorphic features and processes of the Shivwits Plateau, Arizona, and their constraints on the age of western Grand Canyon. Colorado River Origin and Evolution: Grand Canyon, Arizona, Grand Canyon Association, Monograph 12, 65-70.

Lucchitta, I., Holm, R. F., Lucchitta, B. K., 2013. Implications of the Miocene (?) Crooked Ridge River of northern Arizona for the evolution of the Colorado River and Grand Canyon. Geosphere 9 (6), 1417-1433, doi: 10.1130/GES00861.1.

Matthes, F. E., 1972. Geologic history of the Yosemite Valley. In: Glaciers and Glacial Erosion. Springer, pp. 92-118.

Medvedev, S., Souche, A., Hartz, E., 2013. Influence of ice sheet and glacial erosion on passive margins of Greenland. Geomorphology 193, 36-46, doi: 10.1016/j.geomorph.2013.03.029.

Moon, S., Chamberlain, C. P., Blisniuk, K., Levine, N., Rood, D. H., Hilley, G. E., 
2011. Climatic control of denudation in the deglaciated landscape of the Washington Cascades. Nature Geoscience 4 (7), 469-473, doi:10.1038/ngeo1159.

Morlighem, M., Williams, C. N., Rignot, E., An, L., Arndt, J. E., Bamber, J. L., Catania, G., Chauché, N., Dowdeswell, J. A., Dorschel, B., et al., 2017. BedMachine v3: Complete bed topography and ocean bathymetry mapping of Greenland from multibeam echo sounding combined with mass conservation. Geophysical Research Letters 44 (21), 11-051, doi:10.1002/2017GL074954.

Mudd, S. M., Attal, M., Milodowski, D. T., Grieve, S. W. D., Valters, D. A., 2014. A statistical framework to quantify spatial variation in channel gradients using the integral method of channel profile analysis. Journal of Geophysical Research: Earth Surfacedoi:10.1002/2013JF002981.

Neely, A. B., Bookhagen, B., Burbank, D. W., 2017. An Automated Knickzone Selection Algorithm (KZ-Picker) to Analyze Transient Landscapes: Calibration and Validation. Journal of Geophysical Research: Earth Surface, doi: 10.1002/2017JF004250.

Neteler, M., Bowman, M., Landa, M., Metz, M., 2012. GRASS GIS: a multipurpose Open Source GIS. Environmental Modelling \& Software 31, 124-130, doi:10.1016/j.envsoft.2011.11.014.

Oskin, M., Burbank, D. W., Dec. 2005. Alpine landscape evolution dominated by cirque retreat. Geology 33, 933-937, doi:10.1130/G21957.1.

Ouimet, W. B., Whipple, K. X., Royden, L. H., Sun, Z., Chen, Z., 2007. The influence of large landslides on river incision in a transient landscape: Eastern 
margin of the Tibetan Plateau (Sichuan, China). Geological Society of America Bulletin 119 (11-12), 1462-1476, doi:10.1130/B26136.1.

Ouimet, W. B., Whipple, K. X., Granger, D. E., 2009. Beyond threshold hillslopes: Channel adjustment to base-level fall in tectonically active mountain ranges. Geology 37 (7), 579-582, doi:10.1130/G30013A.1.

Palucis, M. C., Dietrich, W. E., Hayes, A. G., Williams, R. M., Gupta, S., Mangold, N., Newsom, H., Hardgrove, C., Calef, F., Sumner, D. Y., 2014. The origin and evolution of the Peace Vallis fan system that drains to the Curiosity landing area, Gale Crater, Mars. Journal of Geophysical Research: Planets 119 (4), 705-728, doi:0.1002/2013JE004583.

Pelletier, J. D., 2010. Numerical modeling of the late Cenozoic geomorphic evolution of Grand Canyon, Arizona. Geological Society of America Bulletin 122 (34), 595-608, doi:10.1130/B26403.1.

Penck, W., Czech, H., Boswell, K. C., 1972. Morphological analysis of land forms: a contribution to physical geology. Hafner Publishing Company.

Perron, J. T., Royden, L., 2013. An integral approach to bedrock river profile analysis. Earth Surface Processes and Landforms 38, 570-576, doi: 10.1002/esp.3302.

Powell, J. W., 1875. Exploration of the Colorado River of the West and its Tributaries.

Ramsey, L. A., Walker, R. T., Jackson, J., 2007. Geomorphic constraints on the active tectonics of southern Taiwan. Geophysical Journal International 170 (3), 1357-1372, doi:10.1111/j.1365-246X.2007.03444.x. 
Riebe, C. S., Kirchner, J. W., Granger, D. E., Finkel, R. C., 2001. Minimal climatic control on erosion rates in the Sierra Nevada, California. Geology 29 (5), 447450, doi:10.1130/0091-7613(2001)?029;0447:MCCOER ¿?.

Roberts, G. G., White, N., 2010. Estimating uplift rate histories from river profiles using African examples. Journal of Geophysical Research 115 (B2), B02406, doi:10.1029/2009JB006692.

Roberts, G., White, N., Martin-Brandis, G., Crosby, A., 2012. An uplift history of the Colorado Plateau and its surroundings from inverse modeling of longitudinal river profiles. Tectonics 31 (4), doi:10.1029/2012TC003107.

Rosenbloom, N. A., Anderson, R. S., 1994. Hillslope and channel evolution in a marine terraced landscape, Santa Cruz, California. Journal of Geophysical Research 99 (B7), 14013-14030, doi:10.1029/94JB00048.

Ross, D., 1976. Geologic map of the Waucoba Wash quadrangle, Inyo County, California. Geologic quadrangle map gq-612, scale 1:62,500, U.S. Geological Survey.

Royden, L., Perron, J. T., 2013. Solutions of the stream power equation and application to the evolution of river longitudinal profiles. Journal of Geophysical Research: Earth Surface 118 (2), 497-518, doi:10.1002/jgrf.20031.

Rudge, J. F., Roberts, G. G., White, N. J., Richardson, C. N., 2015. Uplift histories of Africa and Australia from linear inverse modeling of drainage inventories. Journal of Geophysical Research: Earth Surface 120 (5), 894-914, doi: 10.1002/2014JF003297. 
Sambridge, M., 1990. Non-linear arrival time inversion: constraining velocity anomalies by seeking smooth models in 3-D. Geophysical Journal International 102 (3), 653-677, doi:10.1111/j.1365-246X.1990.tb04588.x.

Scheingross, J. S., Lo, D. Y., Lamb, M. P., 2017. Self-formed waterfall plunge pools in homogeneous rock. Geophysical Research Letters 44 (1), 200-208, doi:10.1002/2016GL071730.

Schildgen, T. F., Cosentino, D., Bookhagen, B., Niedermann, S., Yıldırım, C., Echtler, H., Wittmann, H., Strecker, M. R., 2012. Multi-phased uplift of the southern margin of the Central Anatolian plateau, Turkey: A record of tectonic and upper mantle processes. Earth and Planetary Science Letters 317, 85-95, doi:10.1016/j.eps1.2011.12.003.

Schoenbohm, L., Whipple, K., Burchfiel, B., Chen, L., 2004. Geomorphic constraints on surface uplift, exhumation, and plateau growth in the Red River region, Yunnan Province, China. Geological Society of America Bulletin 116 (78), 895-909, doi:10.1130/B25364.1.

Segall, P., Harris, R., 1987. Earthquake deformation cycle on the San Andreas fault near Parkfield, California. Journal of Geophysical Research: Solid Earth 92 (B10), 10511-10525.

Seidl, M. A., Dietrich, W. E., 1993. The problem of channel erosion into bedrock. Catena supplement 23, 101-101.

Sklar, L., Dietrich, W. E., 1998. River Longitudinal Profiles and Bedrock Incision Models: Stream Power and the Influence of Sediment Supply. In: Tinkler, K. J., 
Wohl, E. E. (Eds.), Rivers Over Rock: Fluvial Processes in Bedrock Channels. American Geophysical Union, pp. 237-260, doi:10.1029/GM107p0237.

Sklar, L. S., Dietrich, W. E., 2001. Sediment and rock strength controls on river incision into bedrock. Geology 29 (12), 1087-1090.

Sklar, L. S., Dietrich, W. E., 2004. A mechanistic model for river incision into bedrock by saltating bed load. Water Resources Research 40 (6), doi: 10.1029/2003WR002496.

Small, E. E., Anderson, R. S., Feb. 1998. Pleistocene relief production in Laramide mountain ranges, western United States. Geology 26, 123-127.

Steer, P., Huismans, R. S., Valla, P. G., Gac, S., Herman, F., 2012. Bimodal PlioQuaternary glacial erosion of fjords and low-relief surfaces in Scandinavia. Nature Geoscience 5 (9), 635-639, doi:10.1038/ngeo1549.

Sternai, P., Herman, F., Champagnac, J.-D., Fox, M., Salcher, B., Willett, S. D., 2012. Pre-glacial topography of the European Alps. Geology 40 (12), 10671070, doi:10.1130/G33540.1.

Stokes, M., Mather, A., Rodés, Á., Kearsey, S., Lewin, S., 2018. Anatomy, Age and Origin of an Intramontane Top Basin Surface (Sorbas Basin, Betic Cordillera, SE Spain). Quaternary 1 (2), 15 doi:10.3390/quat1020015.

Streitz, R., Stinson, M., 1974. Geologic map of California : Death Valley sheet. scale 1:250,000, California Division of Mines and Geology.

Strunk, A., Knudsen, M. F., Egholm, D. L., Jansen, J. D., Levy, L. B., Jacobsen, B. H., Larsen, N. K., 2017. One million years of glaciation and de- 
nudation history in west Greenland. Nature communications 8, 14199, doi: 10.1038/ncomms 14199.

Sugden, D. E., 1974. Landscapes of glacial erosion in Greenland and their relationship to ice, topographic and bedrock conditions. Inst. Br. Geogr. Spec. Publ. 7,177195 .

Tucker, G. E., Slingerland, R. L., 1994. Erosional dynamics, flexural isostasy, and long-lived escarpments: A numerical modeling study. Journal of Geophysical Research: Solid Earth 99 (B6), 12, doi:10.1029/94JB00320.

Tucker, G. E., Slingerland, R., 1997. Drainage basin responses to climate change. Water Resources Research 33 (8), 2031-2047, doi:10.1029/97WR00409.

Turowski, J. M., Lague, D., Crave, A., Hovius, N., 2006. Experimental channel response to tectonic uplift. Journal of Geophysical Research: Earth Surface 111 (F3), 2156-2202, doi:10.1029/2005JF000306.

Valla, P. G., Shuster, D. L., Van Der Beek, P. A., 2011. Significant increase in relief of the European Alps during mid-Pleistocene glaciations. Nature geoscience 4 (10), 688, doi:10.1038/ngeo1242.

Van der Beek, P., Bourbon, P., 2007. A quantification of the glacial imprint on relief development in the French western Alps. Geomorphology doi: doi:10.1016/j.geomorph.2007.02.038.

Van Gorp, W., Temme, A., Veldkamp, A., Schoorl, J., 2015. Modelling long-term (300 ka) upland catchment response to multiple lava damming events. Earth surface processes and landforms 40 (7), 888-900, doi:10.1002/esp.3689. 
Von Blanckenburg, F., 2005. The control mechanisms of erosion and weathering at basin scale from cosmogenic nuclides in river sediment. Earth and Planetary Science Letters 237 (3), 462-479, doi:10.1016/j.eps1.2005.06.030.

Wang, P., Zheng, H., Liu, S., 2012. Geomorphic constraints on Middle Yangtze River reversal in eastern Sichuan Basin, China. Journal of Asian Earth Sciences 69, 70-85, doi:10.1016/j.jseaes.2012.09.018.

Wessel, P., Smith, W. H., Scharroo, R., Luis, J., Wobbe, F., 2013. Generic mapping tools: improved version released. Eos, Transactions American Geophysical Union 94 (45), 409-410, doi:10.1002/2013EO450001.

West, A. J., Fox, M., Walker, R. T., Carter, A., Harris, T., Watts, A. B., Gantulga, B., 2013. Links between climate, erosion, uplift, and topography during intracontinental mountain building of the Hangay Dome, Mongolia. Geochemistry, Geophysics, Geosystems 14 (12), 5171-5193, doi:10.1002/2013GC004859.

Whipple, K. X., Tucker, G. E., 1999. Dynamics of the stream-power river incision model: Implications for height limits of mountain ranges, landscape response timescales, and research needs. Journal of Geophysical Research: Solid Earth 104 (B8), doi:10.1029/1999JB900120.

Whipple, K. X., Tucker, G. E., 2002. Implications of sediment-flux-dependent river incision models for landscape evolution. Journal of Geophysical Research: Solid Earth 107 (B2), 2039, doi:10.1029/2000JB000044.

Whipple, K. X., DiBiase, R. A., Ouimet, W. B., Forte, A. M., 2017. Preservation or piracy: Diagnosing low-relief, high-elevation surface formation mechanisms. Geology 45 (1), 91-94, doi:10.1130/G38490.1. 
Whittaker, A. C., Boulton, S. J., 2012. Tectonic and climatic controls on knickpoint retreat rates and landscape response times. Journal of Geophysical Research: Earth Surface 117 (F2), doi:10.1029/2011JF002157.

Wickert, A. D., Mitrovica, J. X., Williams, C., Anderson, R. S., 2013. Gradual demise of a thin southern Laurentide ice sheet recorded by Mississippi drainage. Nature 502 (7473), 668-671, doi:10.1038/nature12609.

Willett, S. D., McCoy, S. W., Perron, J. T., Goren, L., Chen, C.-Y., 2014. Dynamic Reorganization of River Basins. Science 343 (6175), doi: 10.1126/science. 1248765 .

Winn, C., Karlstrom, K. E., Shuster, D. L., Kelley, S., Fox, M., 2017. 6 Ma age of carving Westernmost Grand Canyon: Reconciling geologic data with combined AFT,(U-Th)/He, and 4He/3He thermochronologic data. Earth and Planetary Science Letters 474, 257-271, doi:10.1016/j.epsl.2017.06.051.

Wittmann, H., von Blanckenburg, F., Kruesmann, T., Norton, K. P., Kubik, P. W., 2007. Relation between rock uplift and denudation from cosmogenic nuclides in river sediment in the Central Alps of Switzerland. Journal of Geophysical Research: Earth Surface 112 (F4), F04010, doi:10.1029/2006JF000729.

Wobus, C. W., Crosby, B. T., Whipple, K. X., 2006. Hanging valleys in fluvial systems: Controls on occurrence and implications for landscape evolution. Journal of Geophysical Research: Earth Surface 111 (F2), doi:10.1029/2005JF000406.

Yang, R., Willett, S. D., Goren, L., 2015. In situ low-relief landscape formation as a result of river network disruption. Nature 520 (7548), 526-530, doi: $10.1038 /$ nature14354. 
1082 Yanites, B. J., Tucker, G. E., Mueller, K. J., Chen, Y.-G., Wilcox, T., Huang, S.1083 Y., Shi, K.-W., 2010. Incision and channel morphology across active structures 1084 along the Peikang River, central Taiwan: Implications for the importance of 1085 channel width. Geological Society of America Bulletin 122 (7-8), 1192-1208, 1086 doi:10.1130/B30035.1.

1087 Young, R. A., 1989. Paleogene-Neogene deposits of western Grand Canyon, 1088 Arizona. Geology of Grand Canyon, Northern Arizona (with Colorado 1089 River Guides): Lee Ferry to Pierce Ferry, Arizona, 166-174, doi: $1090 \quad 10.1029 / \mathrm{FT} 115 \mathrm{p} 0166$. 


\section{Pre-incision landscape}

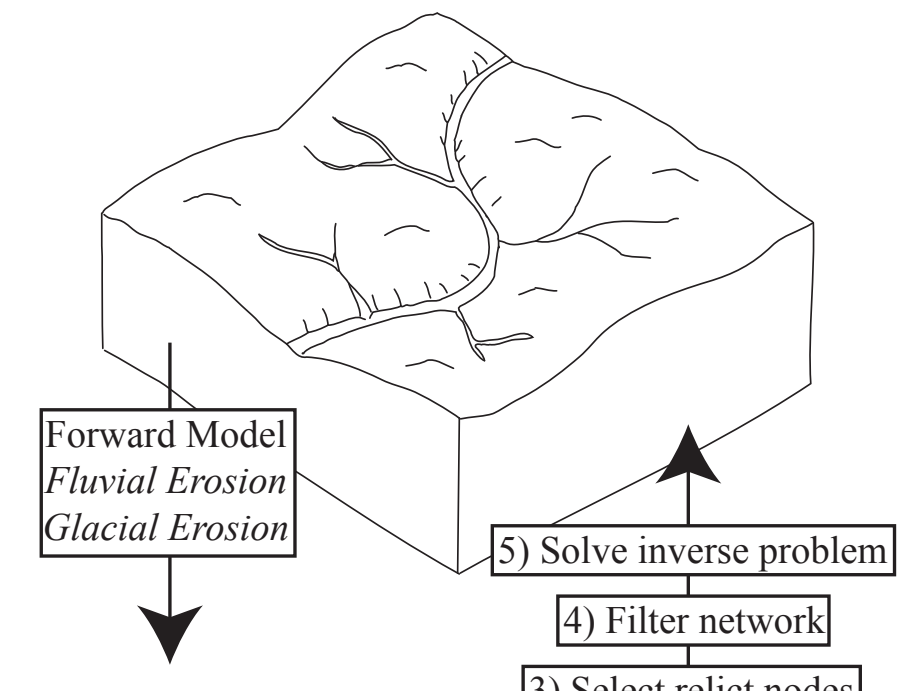

\section{Incised landscape}

3) Select relict nodes

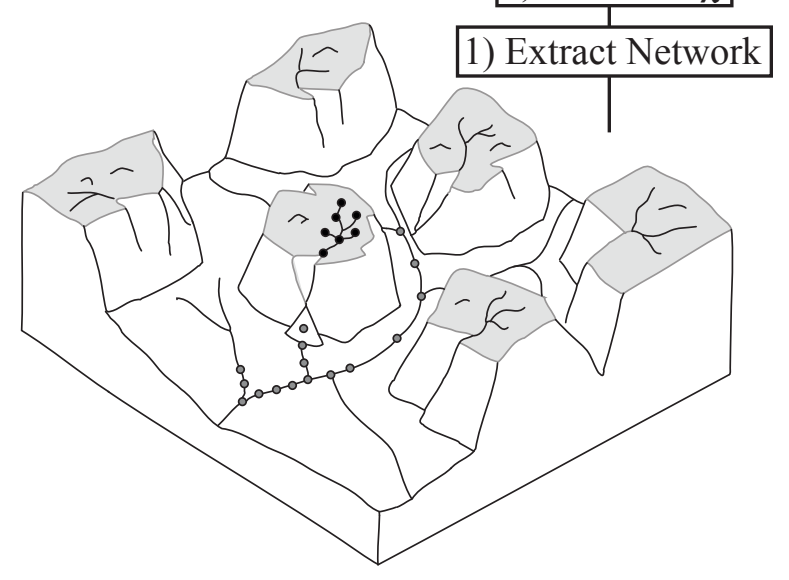

Figure 1: In some settings, low relief landscapes may be incised resulting in modern topography with high-elevation low-relief remnant surfaces. In order to understand erosional processes driving the incision (the forward model), an initial topography is often required for landscape evolution models or to obtain estimates of incision, sediment volume or exhumation. The steps required to solve the corresponding inverse problem (to build an initial topography from remnant surfaces and the modern drainage network), are described on the right of the figure. A representative part of the discrete filtered river network is shown for the remnant surface and the rest of the network as black and gray circles, respectively. 


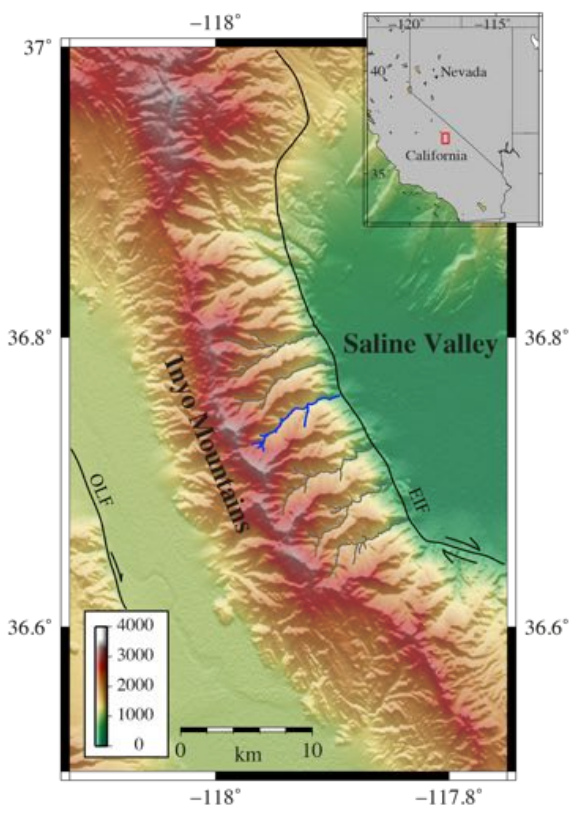

Figure 2: The topography of the Inyo Mountains with the rivers shown in gray draining to the Saline Valley. The McElvoy Canyon is shown in blue. Inset shows the location of the Inyo Mountains with respect to California and Nevada. The black lines are the approximate locations of the Eastern Inyo Fault (EIF) and the Owens Lake Fault (OLF) after Lee et al. (2009). Data source: The National Elevation Dataset (NED) digital elevation model (DEM) (Gesch et al., 2002; Gesch, 2007). 

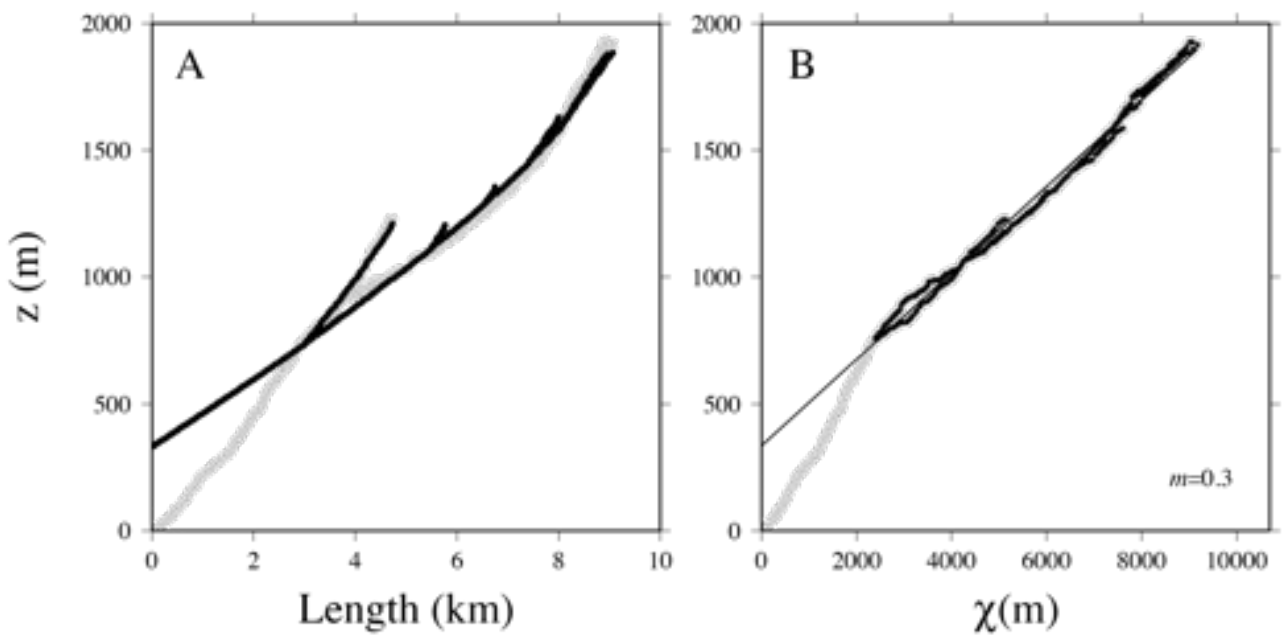

Figure 3: (A) Long-profile of the McElvoy Canyon and its tributaries for river nodes with an upstream drainage area greater that $10 \mathrm{~km}^{2}$, gray curve. The data were extracted from National Elevation Dataset (NED) digital elevation model (DEM) (Gesch et al., 2002; Gesch, 2007). The black points show the reconstructed steady state landscape using the recovered channel steepness and baselevel value. (B) $\chi$-elevation relationship for the McElvoy Canyon and its tributaries, with $m=0.3$ and $A_{0}=1 \mathrm{~km}^{2}$. The black points are the nodes used to constrain the channel steepness and the baselevel parameter, and the black line is the fit to these points. 


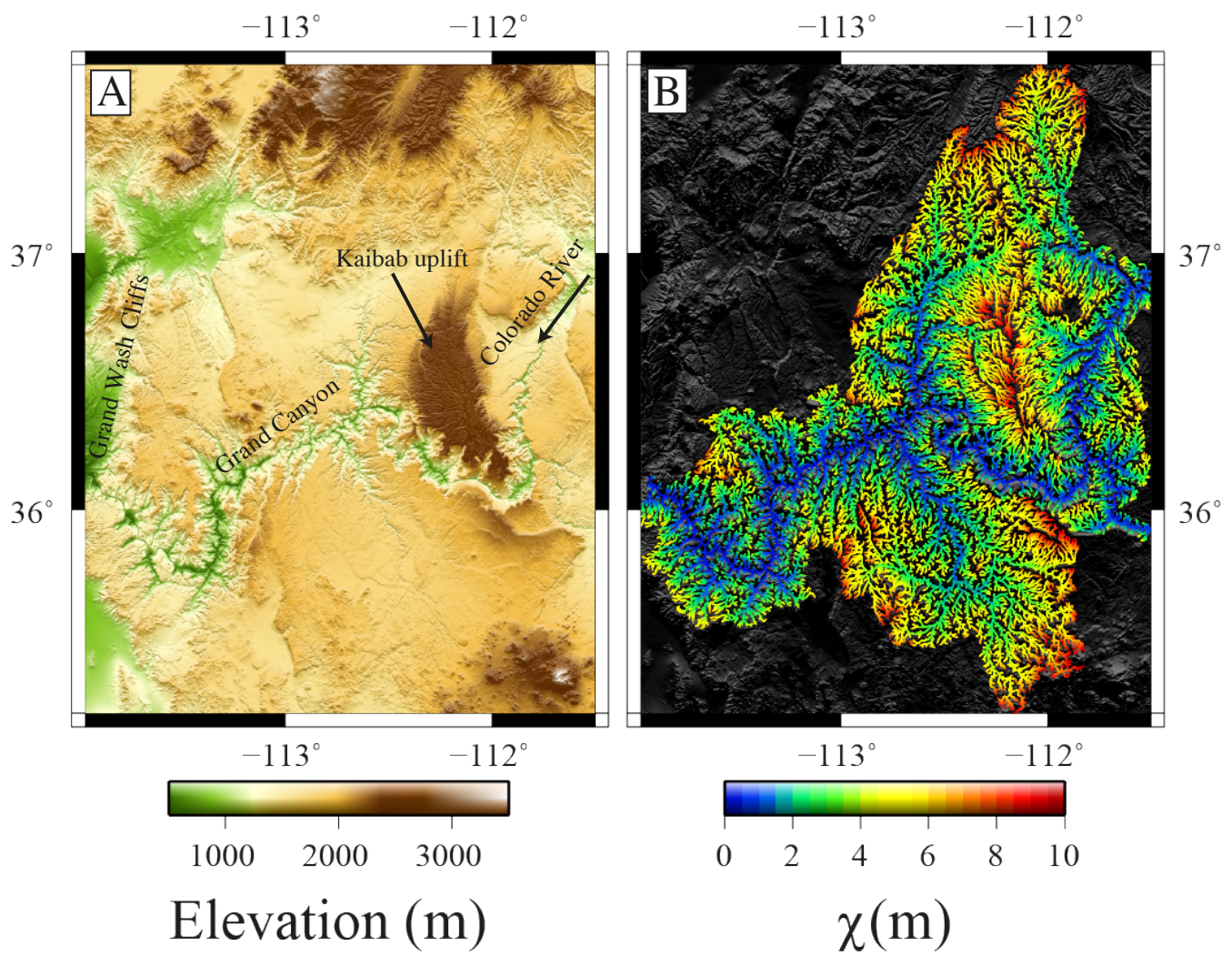

Figure 4: (A) Topography of Grand Canyon showing the deeply incised canyon and surrounding low relief surfaces. However, there is still significant topography across the region, in particular the Kaibab uplift is almost $1 \mathrm{~km}$ higher than the surrounding plains. The upstream course of the Colorado River is shown by the arrow from the east. (B) $\chi$ map of all rivers with an upstream drainage area greater than $1 \mathrm{~km}^{2}$ based on data from (Lehner et al., 2008) that join the main Colorado River between the longitude shown in the figure. The baselevel is defined at the Grand Wash Cliffs and a value of $m=0.5$ and $A_{0}=1 \mathrm{~m}^{2}$ was used to calculate $\chi$. Importantly, the entire upstream drainage area of the Colorado river was used to calculate $\chi$ along the Colorado River. 

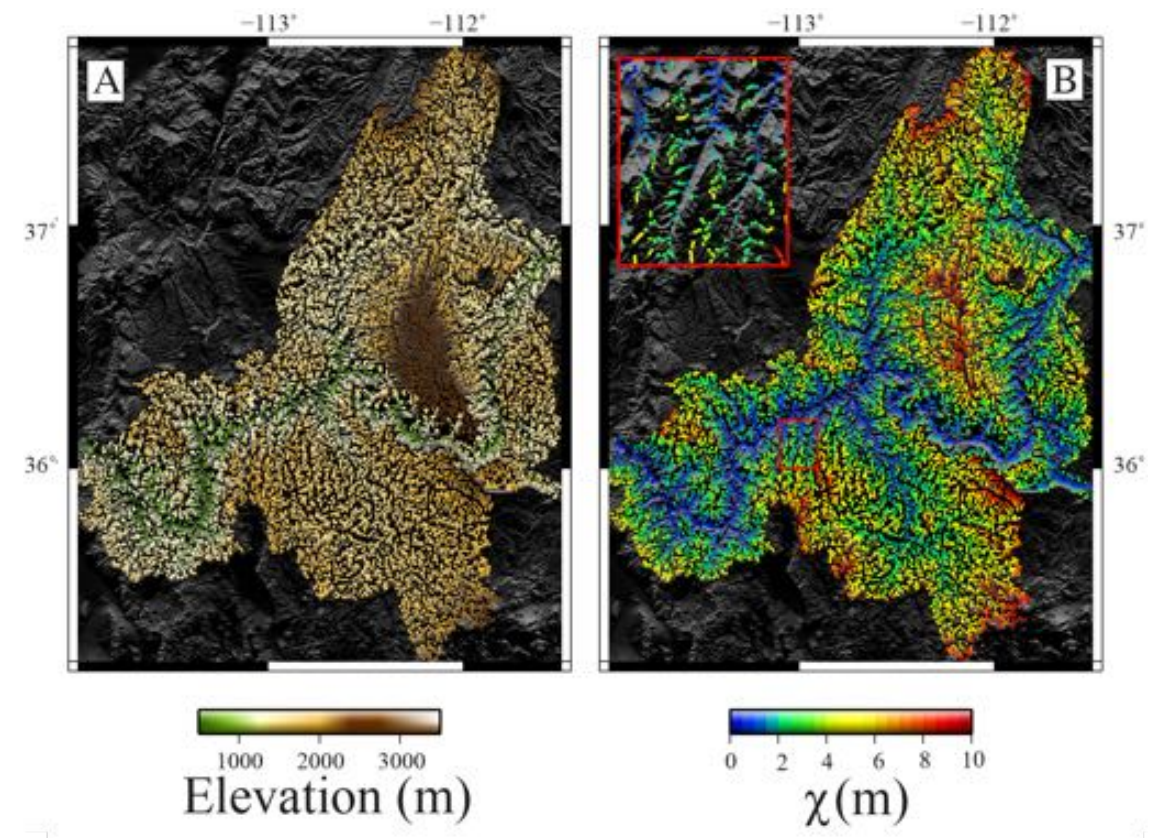

Figure 5: (A) Sampled topography and (B) $\chi$ values used for the inversion. Only nodes that had a $5 \%$ greater upstream drainage area than the node upstream were selected. This reduces the number of nodes used in the analysis by a factor of $\sim 7$ (from 246,907 to 36,458). It is important to note that the complete dataset was used to calculate $\chi$. 

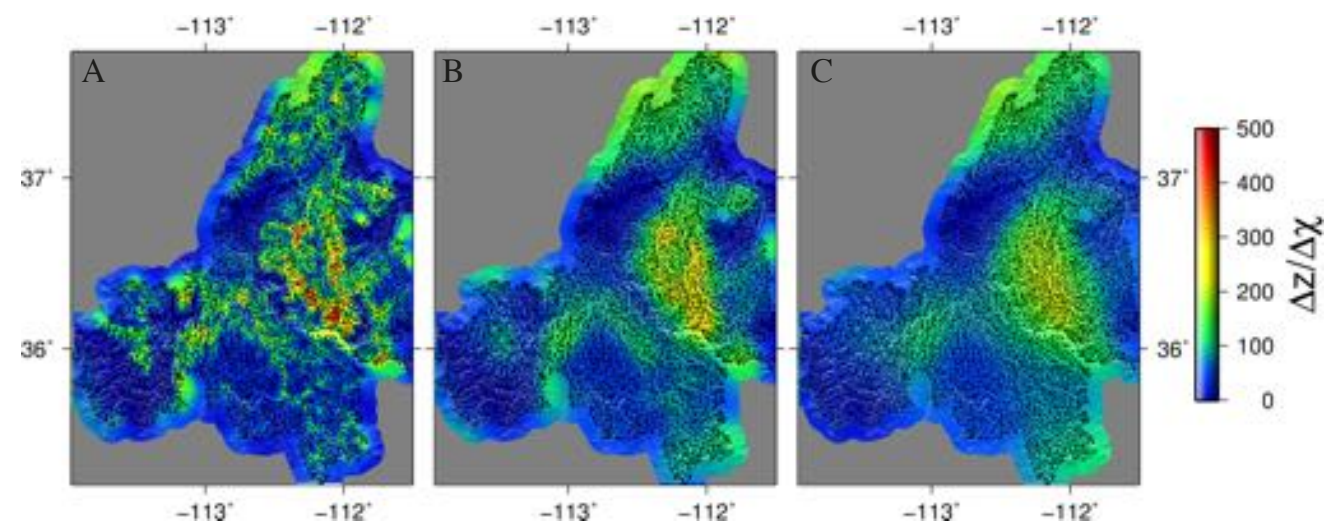

Figure 6: Model dependence on the smoothness parameter. (A) $\lambda=0.1$, (B) $\lambda=2$, and (C) $\lambda=10$. The $\Delta z / \Delta \chi$ is the normalized rock uplift rate. The inferred baselevel values for these results are 1491,1500 and 1457 for $\lambda=0.1, \lambda=2$. and $\lambda=10$ respectively. 


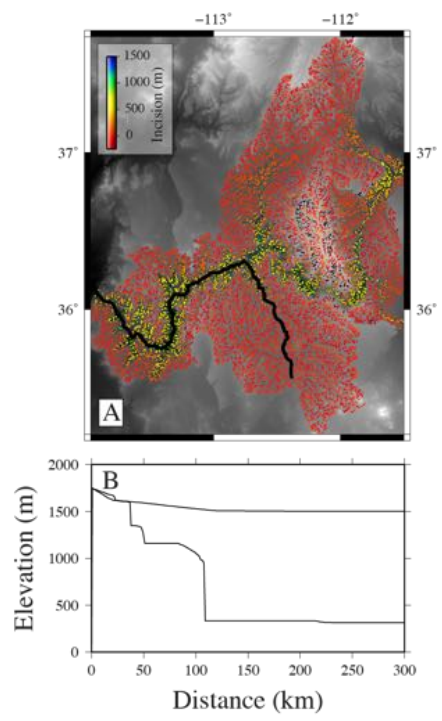

Figure 7: Example result for $\lambda=2$. We show the calculated difference between the reconstructed topography at the sampled node locations (A) and an example of a river long profile (B). Differences between the reconstructed topography and the modeled topography are associated with either changes in the baselevel or data misfit, i.e., the inability to fit the modern river nodes given the smoothness constraints and discretization scheme. Differences associated with changes in the baselevel are clearest within Grand Canyon. Data misfit is most pronounced within the Kaibab Uplift close to the Grand Canyon. 


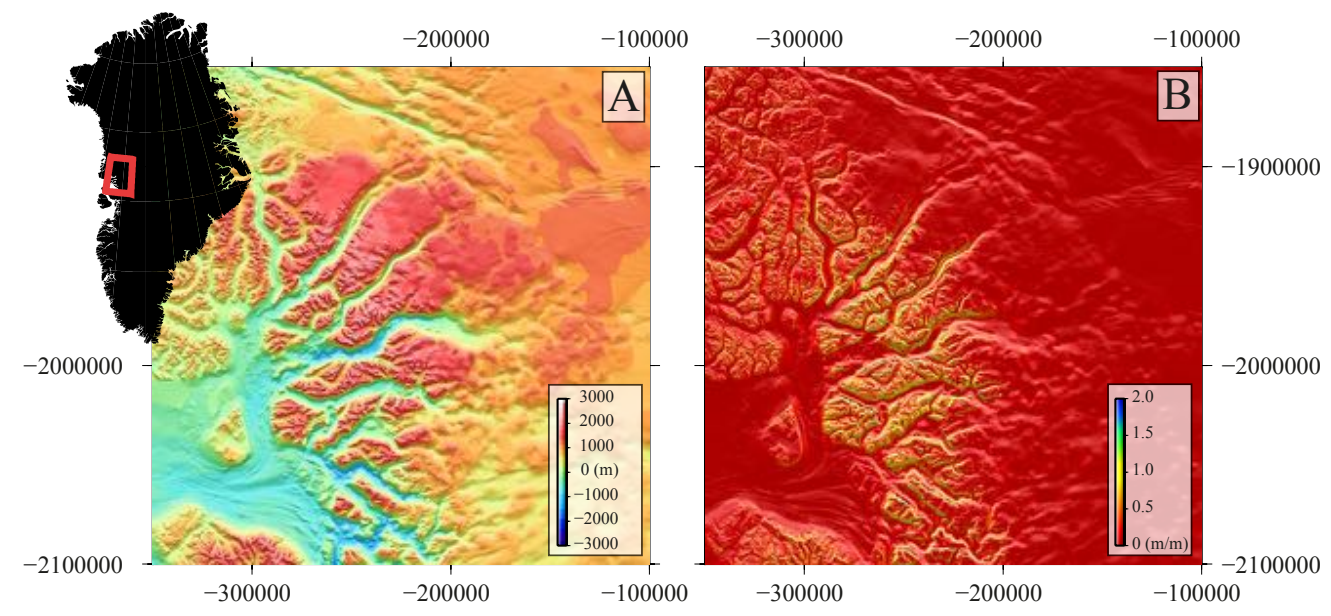

Figure 8: (A) The topography of the Karrat region showing deep glacial valleys and high remnant parts of the landscape. The projection for this map is the Polar Stereographic North projection, with a central meridian of $45^{\circ} \mathrm{W}$ and standard parallel of $70^{\circ} \mathrm{N}$, and the $x$ and $y$ axes have units of meters in this projection. (B) The slope map for the Karrat region highlighting the steepened walls of the glacial troughs and the relatively low slope of the high elevation portion of the landscape. 
A) Filtered $\chi$ values

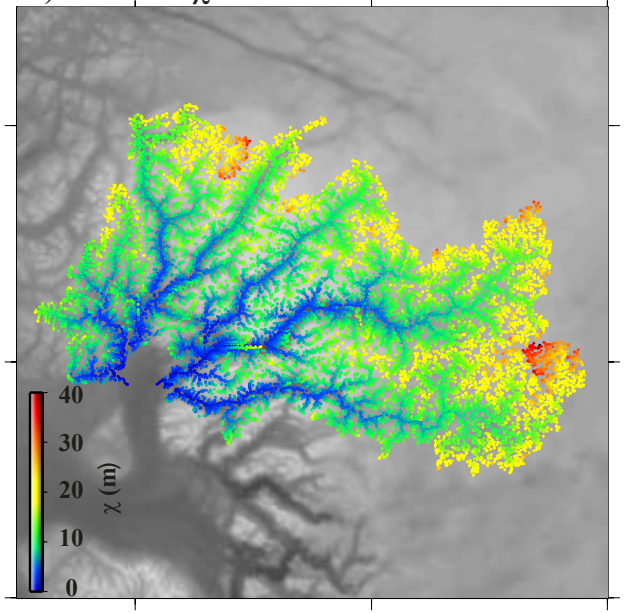

C) Filtered topography

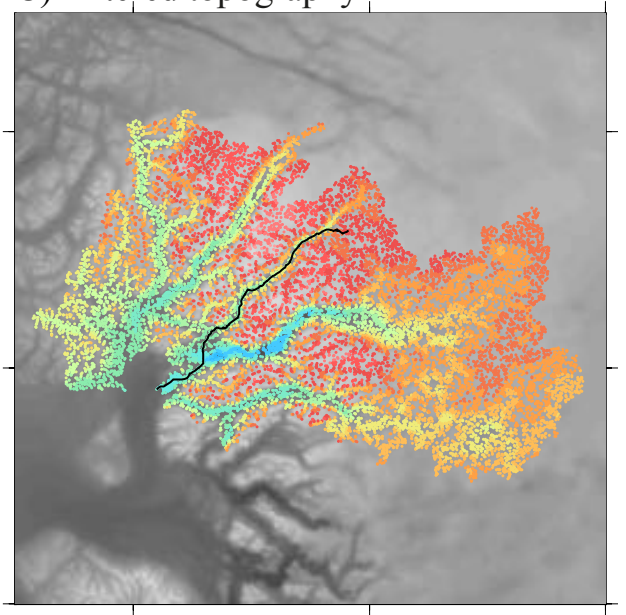

B) Selected relict remnants

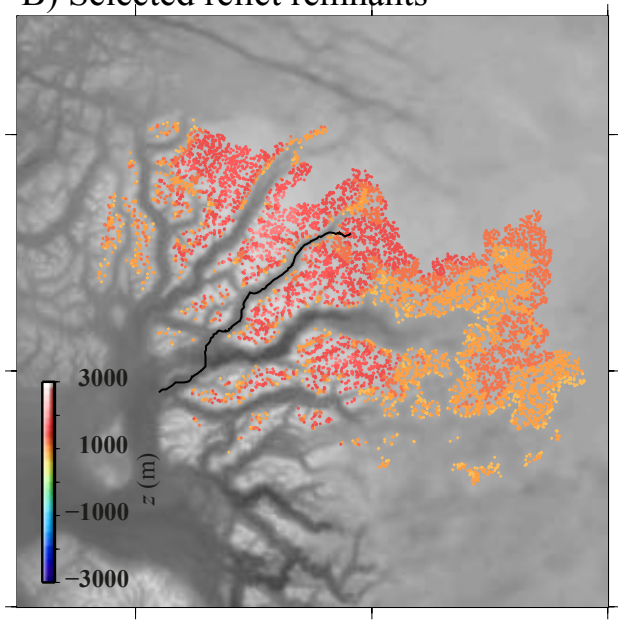

D) Predicted pre-incision topography

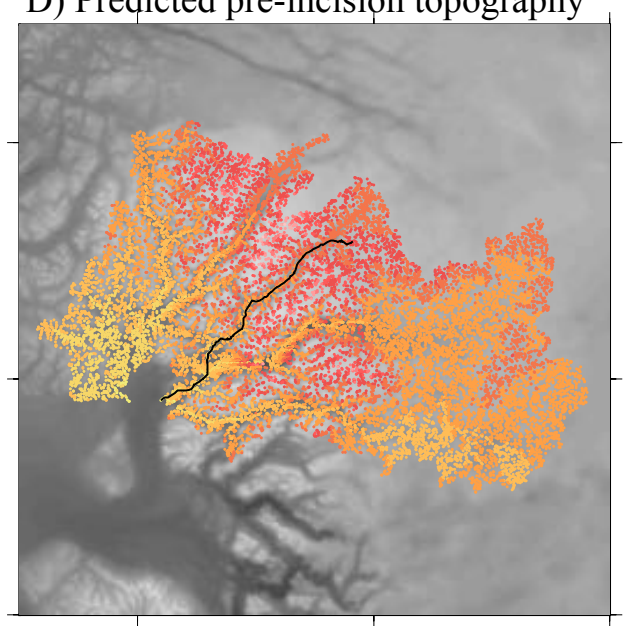

Figure 9: (A) The $\chi$ values for the Karrat region. The total dataset was filtered after the full dataset was used to calculate $\chi$, so that only $20 \%$ of the nodes were chosen at random. (B) The locations of high remnant parts of the topography used in the inversion. These were selected at elevations greater than $850 \mathrm{~m}$ and for slopes less than $0.6 \mathrm{~m} / \mathrm{m}$. The criteria for selecting these remnants would strongly influence the results and this should be explored for further applications. (C) The elevations of the filtered nodes and these are shown to help comparison with the recovered preincision topography. Only the elevations shown in (B) are used in the inversion. (D) The predicted pre-incision topography showing that the glacial troughs have been filled in with a river valley, determined by the normalized rock uplift rate and the baselevel parameter, which is $579.8 \mathrm{~m}$. 

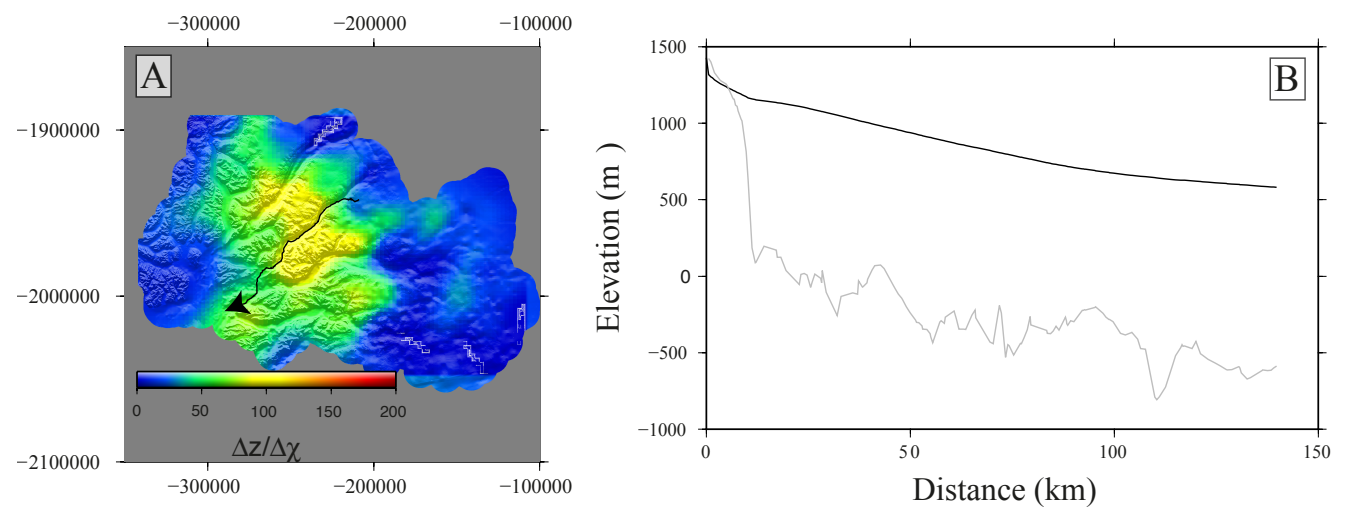

Figure 10: (A) The inversion results highlight an area of high normalized rock uplift rate across the centre of the analyzed area. (B) A river cutting through this area is inferred to have high along-channel slopes at high elevations where drainage area is small. As the river flows into the area of high normalized rock uplift rate, the slopes decrease before increasing downstream of the area. The slopes decrease again due to the increasing upstream drainage area and slightly lower normalized rock uplift rate. 